ADMINISTRATOR VIEW ON TECHNOLOGY DIRECTORSHIP IN SOUTHEAST MISSOURI

MISSOURI

A Dissertation

Presented to

The Faculty of the Graduate School

At the University of Missouri-Columbia

In Partial Fulfillment of the Requirements for the Degree

Doctor of Education

by

Floyd H. Lockhart III

Dr. Paul Watkins, Dissertation Supervisor

December, 2018 
(C) Copyright by Floyd H. Lockhart III, 2018

All Rights Reserved 
The undersigned, appointed by the dean of the Graduate School, have examined the dissertation entitled

\section{ADMINISTRATOR VIEW ON TECHNOLOGY DIRECTORSHIP IN SOUTHEAST MISSOURI}

presented by Floyd H. Lockhart III, a candidate for the degree of doctor of education, and hereby certify that, in their opinion, it is worthy of acceptance.

Professor Paul Watkins

Professor Simin Cwick

Professor William Bratberg

Professor David Stader 


\section{DEDICATIONS}

Thanks, Mom, Dad, and Gelanie. And to my grandparents, who did not get to see me finish.

Misty and Milli, thank you both... and your dissertations are next! 


\section{ACKNOWLEDGEMENTS}

I would like to thank Dr. Watkins for chairing the committee, Dr. Ruth Ann Roberts for originally guiding me through the early stages of the study, Dr. Bratberg for helping narrow my overlarge survey down to something stakeholders would actually take, Dr. Stader for his words of encouragement along the way, and Dr. Cwick for getting me started on the entire pathway of the program as well as offering her office many times throughout the entire trip. Thank you all for putting up with me as this was developed and birthed. 


\section{TABLE OF CONTENTS}

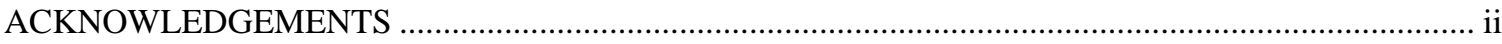

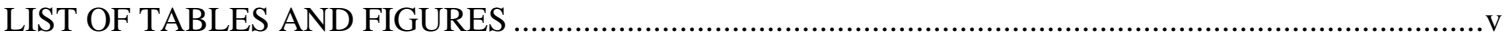

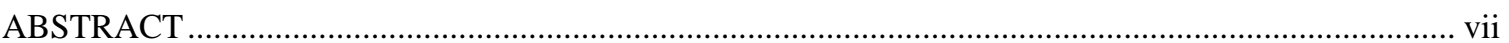

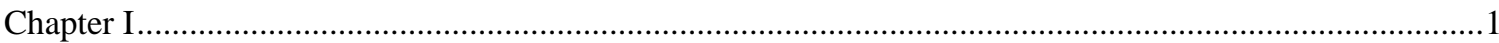

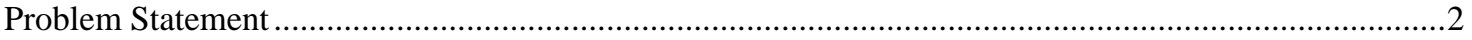

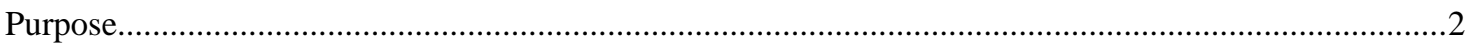

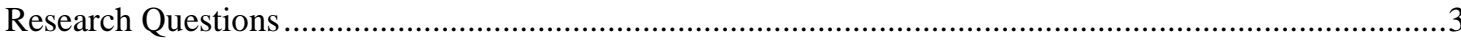

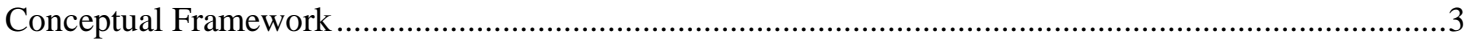

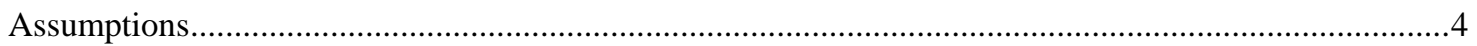

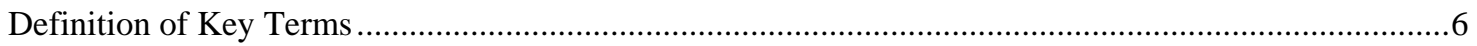

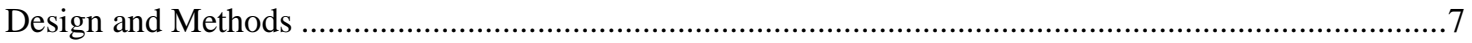

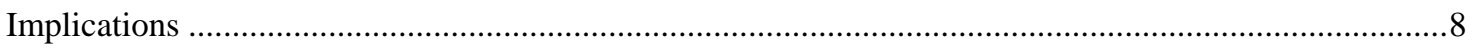

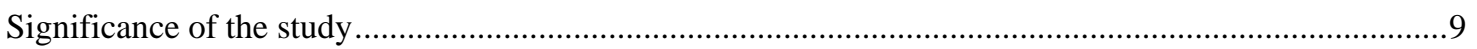

Summary

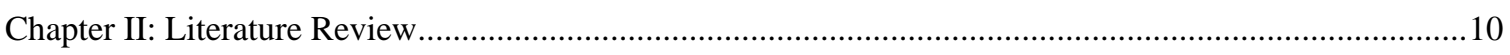

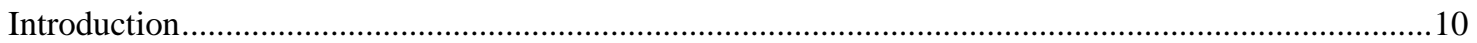

History ……

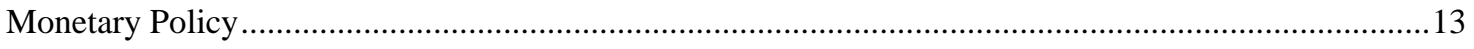

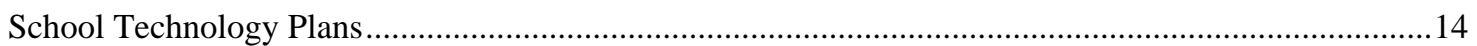

Instructional and Faculty Development Policy ……..........................................................................

Summary

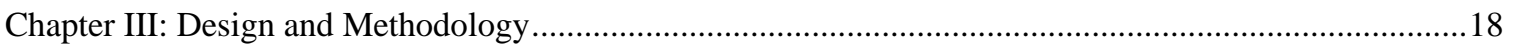

Purpose

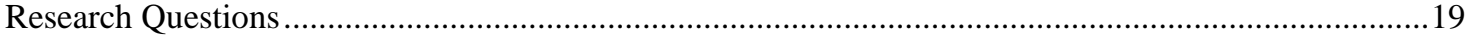

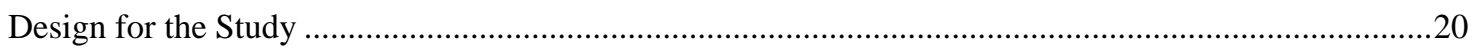

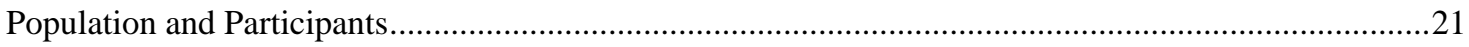

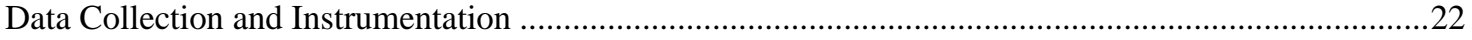




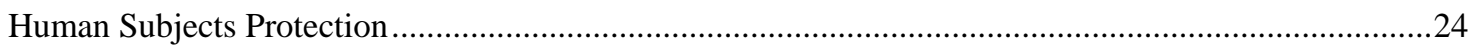

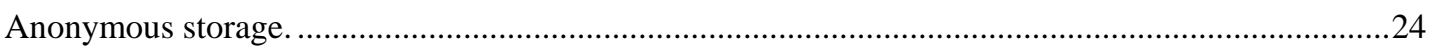

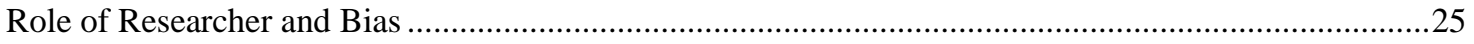

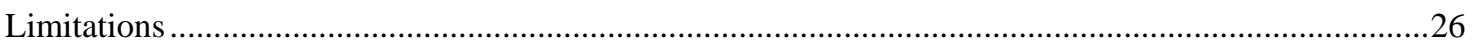

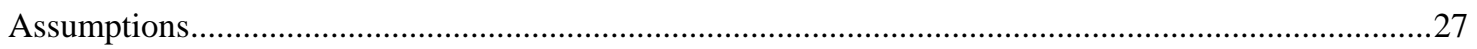

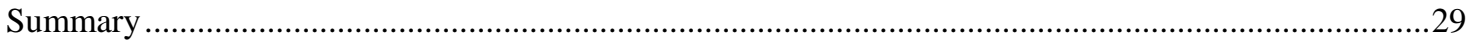

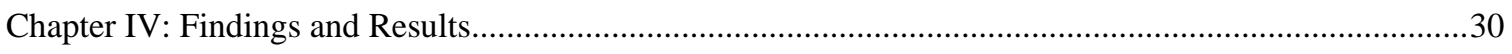

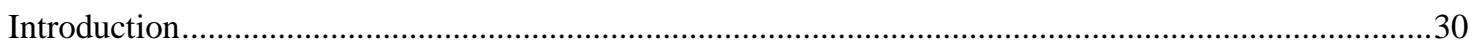

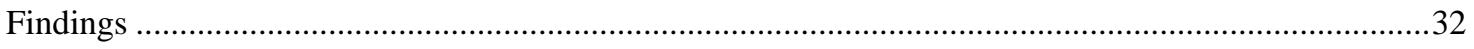

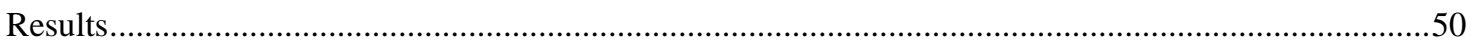

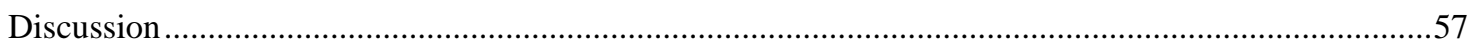

Summary

Chapter V: Conclusions, Implications, and Recommendations. ...............................................................63

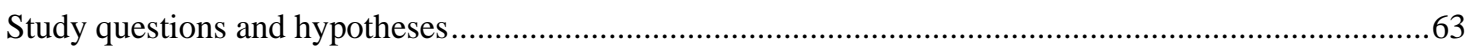

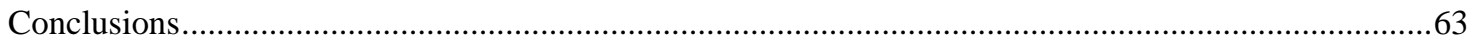

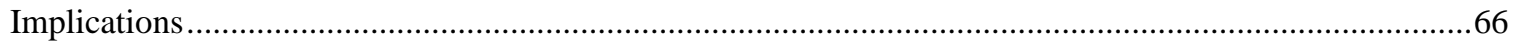

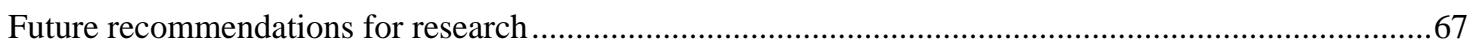

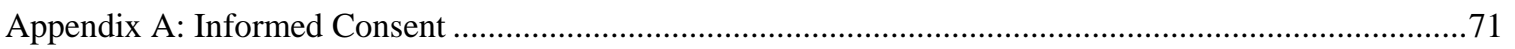

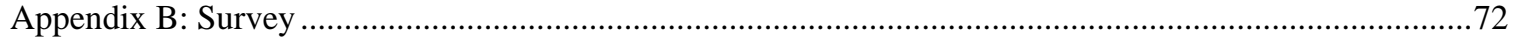

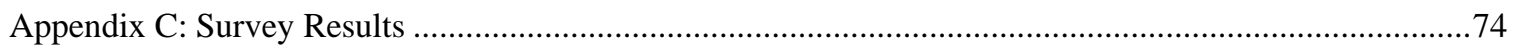

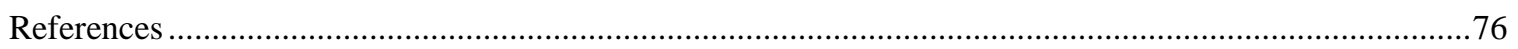

Vita 


\section{LIST OF TABLES AND FIGURES}

Figure

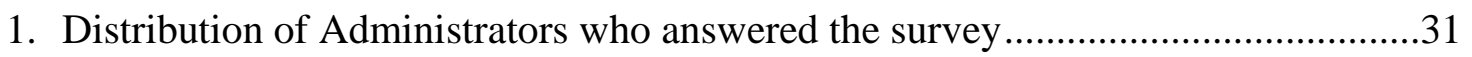

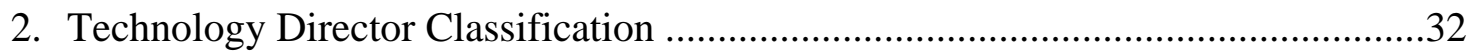

Table

1. Distribution of Administrators who answered the survey .....................................31

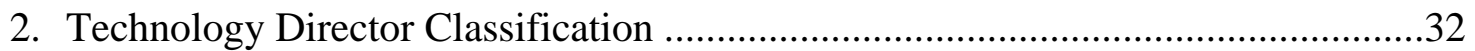

3. Type of Administrator * Be able to plan a building's network infrastructure .........33

4. Type of Administrator * Be able to set up, design, and develop a classroom learning space

5. Type of Administrator * Conduct experiments, analyze data, interpret and apply results to solve problems related to optimizing systems and processes

6. Type of Administrator * Prioritize and project maintenance, sustainability, and growth costs

7. Type of Administrator * Create and maintain a replacement cycle for software and hardware resources.

8. Type of Administrator * Configure routers to use routing protocols in a network topology.....

9. Type of Administrator * Articulate issues concerning ethics for building computer resources

10. Type of Administrator * Articulate issues concerning security personal safety for district computer resources

11. Type of Administrator * Articulate issues concerning copyright and acceptable use for district computer resources

12. Type of Administrator * Develop internet or computer based instructional modules.

13. Create multimedia presentations (audio podcasts, video podcasts, and similar presentations) for use in educational settings.....

14. Type of Administrator * Create an individual professional development plan to increase teacher instructional technology skills 
15. Type of Administrator* Analyze current issues and trends in educational

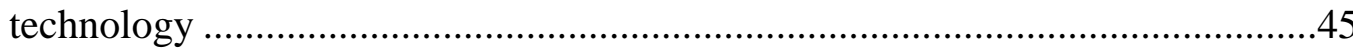

16. Type of Administrator * Develop a building technology plan for teaching

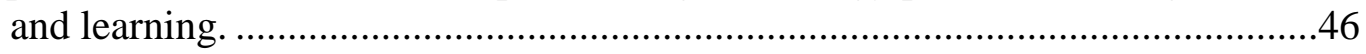

17. Type of Administrator * The Technology Director's role is the function of his

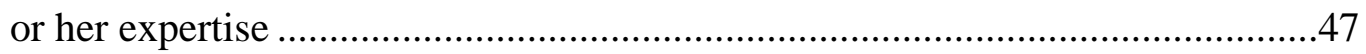

18. Type of Administrator * The Technology Director's role is the function of his or her position in the district...............................................................................48 


\title{
ADMINISTRATOR VIEW ON TECHNOLOGY DIRECTORSHIP IN SOUTHEAST MISSOURI
}

\author{
Floyd H. Lockhart III
}

\author{
Dr. Paul Watkins, Dissertation Supervisor
}

\begin{abstract}
The purpose of this inquiry study is to discover how district school administrators perceive the directorship skills needed for a successful technology director in Missouri. At this stage in the research, the skill needs will be defined as technological proficiencies, curriculum understanding design proficiencies, and the understanding on fitting both the previous skill sets to form solid growth plans for their districts through the lens of Mitzberg's theory on organizations. The application of said technological proficiencies is a direct job function relating to the standardization of work objects, and fits with the Mintzberg definition of a job within the technostructure. Similarly, curriculum understanding of design proficiencies and how those apply is related to the function of standardizing skill flow and development within an organization; this fits the Mintzberg definition of a job within the support structure of an organization.

This study is to examine how the directorship is seen through the lenses of a technical developer and through the lenses as an instructional designer by the district administrators of their organization. Essentially, as a nuts and bolts technician and/or as a person who is responsible for helping the faculty of a district effectively use the systems that the district has built.
\end{abstract}


Running head: ADMINISTOR VIEW ON TECHNOLOGY DIRECTORSHIP IN SOUTHEAST MISSOURI 1

\section{Chapter I}

District technology directors have an important role in today's school districts. The requirements for the job, however, are ill-defined at the district level or state-wide. Current research is oftentimes tied to what a teacher or instructor is doing in the classroom (Jacobs, 2010), and rarely addresses what skills or infrastructure the district should have already in place to provide for the teachers' technological development. Thus, now is the time to examine the role and skills of the development of a technology director, and how to improve the direction that role is taking in the $21^{\text {st }}$ Century.

Because the role of technology director in schools is emerging and ill-defined, the technology directors themselves are constructing their own knowledge and understanding of their role in the district. This process is outlined by Calas (Calas, Smircich 1999) in his discussion over the postmodern approach of struggling towards knowledge.

However, this approach developed over time without a common vision (Usselman, 2010). This view needs comparison to the more structured views with strong legitimate roots. Mintzberg's approach to viewing organizations and their constituent sub_organs offers one such contrast: if the position of the technology director is seen through the lens that the position strives for standardization in the overall organization, it can be directly compared to Mintzberg's technostructure (Mintzberg, 1979).

The technostructure approach helps in defining the relationship between how the position can and should interrelate with the rest of the organization. The relationship between the school administrator and the technology director involves the discussion of power, both legitimate and expert, in how these two roles interrelate (French and Raven, 1959). 


\section{Problem Statement}

The definition, goals, and direction of what a technology director is and should become is ill-defined. This harms both how the profession is viewed and how it can develop. A baseline for the profession needs establishment.

\section{Purpose}

The purpose of this inquiry study is to discover how district school administrators perceive the directorship skills needed for a successful technology director in Missouri. At this stage in the research, the skill needs will be defined as technological proficiencies, curriculum understanding design proficiencies, and the understanding on fitting both the previous skill sets to form solid growth plans for their districts. This is to see how the directorship is seen through the lenses of a technical developer and through the lenses as an instructional designer; in other words, as a nuts and bolts technician and/or as a person who is responsible for helping the faculty of a district effectively use the systems that the district has built. One point in this discussion would be an analysis of how money has affected this view through looking at how the relative wealth factor of a district should help control or examine that effect. 


\section{Research Questions}

1. How does an elementary school building administrator's perception of the role of technology director compare to perception of the secondary school building administrator?

- There is no difference between the elementary school building administrator's perception of the role of the technology director and the secondary school building administrator's view.

2. How does a middle school building administrator's perception of the role of technology director compare to perception of the secondary school building administrator?

- There is no difference between the middle school building administrator's perception of the role of the technology director and the secondary school building administrator's view.

3. How does a secondary school building administrator's perception of the role of technology director compare to perception of the technology director?

- There is no difference between the technology director's perception of the role of the technology director and the secondary school building administrator's view.

\section{Conceptual Framework}

The office of technology director fits Mintzberg's definition of the technostructure and should be evaluated and directed in that context (Mintzberg, 1979). 
Therefore, the effectiveness of the district's technology systems is directly impacted by the office of the technology director; how administrators view this position has an impact on how successful the technostructure is in serving technology systems to the overall organization. In this manner, the position needs review, clarification, and structure. Primarily, do the technology directors have the skills and mindsets to serve the needs of the districts' administration? In the traditional district structure, the school administrator has what French and Raven (French and Raven, 1959) calls legitimate power over all the executive functions of the school. Their definition of legitimate power rises from policy, “... a job description... usually species supervisory activities and also designates the person to whom the job holder is responsible for the duties described" (French and Raven, 1959). Thus, this study fits within the scope of an investigative cultural study. However, since the position of the technology director has no set inherent qualification standards, how to view the position must be derived from the administrators' legitimate power. This review of the assumptions, vision, and skills assessment therefore derives from how the administrator(s) view their own district's implementation of the position.

\section{Assumptions}

The first assumption derives from a requirement from the Missouri Department of Elementary and Secondary Education (DESE), namely that every district has a technology plan that addresses several key questions about how the district uses technology (DESE, 2013). This assumption centers around that the plan is well-known 
by the administrator, is supported by the administrator, is well-understood by the administrator, and is not simply a paperwork hurdle that is updated once a year.

The second assumption is that there is a person or collection of people that the administrator appoints to carry out this technology plan. The person with primary responsibility for these actions is the technology directors. In smaller schools this may be a part time position for one individual; for the larger schools, this may be a small staff of people.

The third assumption is that the administrator has a mental framework for what these workers should do and how they do it. This is where the mental framework of the administrator starts playing a major effect upon the questions: those skills may be purely based in the technician side of technology, or those skills may also involve what is traditionally attributed to instructional design with the tools that are already there. Examination of this view is at the core of the study.

The fourth assumption is tied to how the questions will act and the knowledge base the administrator themselves have over how they have mentally defined the position. Namely, while I expect fairly enlightening answers to the qualitative questions of the study, the skill survey towards the end of the questionnaire might exist outside the administrators' comfort level in answering. This may affect how they answered the questions in the qualitative part, as the very act of asking about a proficiency currently not considered at a district may well impact the end answers to the qualitative section. 


\section{Definition of Key Terms}

District technology plan: A district technology plan should focus on integrating technology into the teaching and learning process to transform the way teachers teach and students learn. At the very least, the technology plan should be embedded in or supplement the district's comprehensive school improvement plan (DESE, 2013).

Instructional designer: a person who is primarily focused on how technology is integrated into the teaching and learning process.

Technician: a person who is primarily focused on providing and servicing the infrastructure for technology.

Technology director: the executive or staff member of the district primarily responsible for carrying out the technology district plan.

Technology coordinator: the staff member of the district primarily responsible for implementation directives established by other district administrators.

Technostructure: The individuals and teams working on functions of an organization: they prioritize the standardization of the work process and the supporting factors therein.

Support structure: Staff who work in research and development, as well as training. They focus primarily standardizing skills.

Secondary education: The last three or four years of statutory formal education in the United States educational system.

Elementary education: the formal education forming the first four to eight years of a child's formal education. 
Middle School education: the formal education forming the fifth to eight years of education, primarily between primary and secondary education.

Junior High: the formal education possibly forming the seventh, eighth, and ninth years of education.

Department of Elementary and Secondary Education (DESE): The governmental agency of Missouri responsible for standards and data concerning the statutory formal education in the state. Their goal: the mission of the Missouri Department of Elementary and Secondary Education is to guarantee the superior preparation and performance of every child in school and in life.

\section{Design and Methods}

The focus of this study will be survey driven. District administrators and technology directors will be surveyed. Administrators will be surveyed for their perceptions on the role of technology directorship. Technology directors will also be surveyed for their perspective on their role. Do these administrators and technology directors have a view consistent with Mintzberg's view of the technostructure and the overall organization (Mintzberg, 1979)? Do these groups view the issue of legitimate and expert power in the same context as defined by French and Raven (French and Raven, 1959)?

The construction of the survey has two parts, the first of which garners the quantitative information about the view of the technology director's role. The quantitative questions include seventeen Likert-scale items. The second part of the survey is comprised of an open-ended question that targets the view of the technology director as 
well as that of the administrator. The intent is to use the qualitative section to get a feel for the current state of how technology directors are viewed in the words of the administrators and technology directors themselves. Essentially, do the respective administrators and technology directors have thematic views on the technology director position that match or deviate according to each position? The quantitative questions evaluate if a common ground currently exists to promote the unification of the ideal of the requirements to what a technology director is and does in their profession. Bringing both together should provide illuminative elocution of the state of the education technology director, and perhaps bound the future direction of perception of how the role needs to change.

\section{Implications}

This is directly the cause of this study: how do administrators view the position? Without a commonality of view, definition of the technostructure and future growth of the position cannot be developed with a wide adoption. Therefore, the first step in reviewing and refining a technology director position, is to see how administrators view the position. Once that is established, further research into how to mature the profession can be established.

This study, therefore, is of particular use to universities and districts interested in defining the technology director as a profession. The nature of this study will provide an elocution of the complex nature of the political and role phenomena inherent to the view of the technostructure and main-line organizational structure. 


\section{Significance of the study}

Primarily this study is intended as a basis for curriculum review and development. Once the relative strengths are assessed, skill needs identified, and position of the current technology directorship is identified among the population serving Missouri districts are all identified, the means of elocution on how to improve the process of establishing a standard for education is an uncomplicated means of definition. Therefore, reviewing the modern curriculum to ensure the population is getting the treatment effect to move the technology directors into the skillsets the various districts need for development becomes a matter of refinement and education, instead of one of definition and direction. In short, everyone will get on the same page for moving forward in the development of the field and the requirements by which the position of technology director can be assessed.

\section{Summary}

The position of technology director in public school districts is not well-defined. The views on what makes a good technology director are also varied. In order to determine how the profession should be evaluated, and how to improve the profession, a baseline understanding of how the profession is viewed needs establishment. With that baseline, new and existing programs can be developed or modified at universities to help mature the profession by providing the credentials and skills needed for the members of the profession and the districts they serve. 


\section{Chapter II: Literature Review \\ Introduction}

District technology directors have an important role in today's school districts. The requirements for the job, however, are ill-defined at even the district level, much less county or state-wide. Current research is oftentimes tied to what a teacher or instructor is doing in the classroom, and rarely addresses what skills or infrastructure the district should have already in place to provide for the teachers' technological development (Usselman, 2010). Thus, now is the time to examine the role and skills of the development of a technology director, and how to improve the direction that role is taking in the modern era.

The position itself lies firmly in the technostructure as described by Mintzberg during his seminal work in the late 1970s on organizational structure (Mintzberg, 1979). Indeed, if one were to break down the technocracy element into its own organizational graph, the position of the technology director would be at the strategic apex of the technostructure itself. Therefore, the position itself has a fuzziness associated with it from several viewpoints: simply put, since the technostructure is outside the normal command line of the district, it touches, is affected by, and effects every part of the normal district operation. The technology director position itself lies at the command center of this web of interconnectivity and is usually only understood through the lenses of individual positions along the normal organizational structure.

This situation is a direct result of how the position, and modern instructional technology infrastructure, came into existence in the modern era and how it is viewed by the stakeholders. This view is oftentimes bounded by the stakeholder's individual 
experience. A careful examination of how this interrelation came to be and a consideration of Mintzberg's organizational structure will provide an excellent elocution on the development of the position's future.

\section{History}

To gain a full understanding of the position of technology director as it exists in the realm of education today, first one examine how the position developed from several pressures in the twentieth century. As with many issues that developed in the last century, the Sputnik incident caused a change in the environment of education, and through that disruption, caused the environment by which the educational technostructure coalesced into instructional technology and the position of the technology director.

Steven Usselman (Usselman, 2010) has a thorough review of the process in his 2010 article From Sputnik to SCOT: the Historiography of American Technology; but the outline is fairly simple. Sputnik launched, Congress and the United States of America reacted by redirecting large monetary infrastructure into research and education. The United States already had a strong manufacturing element, and, in the 1950s, controlled a large segment of the world manufacturing economy. Therefore, one of the elements of the perceived education reform involved incorporating technology manufacturing techniques into everyday education (Smith, 1977). Over time, this new emphasis garnered increasing criticism and evaluation, but generally focused more and more technology and technology usage into the classroom (Usselman, 2010).

The result of this pressure resulted in administrators assigning the technological burdens to either those who were available or those whose previous experience led to the belief those individuals had what Raven and French call "expert power." (French and 
Raven, 1959) Essentially, over time, those who were willing to try the new technology tricks and those with proven mastery were given more and more control over those systems (Usselman, 2010). It is important to note that this process started before computers and the general internet; this process was perceived in the 1970s and had a lot of critical literature reviewing the process (Usselman, 2010).

This collection of volunteers and expert powered individuals gained more power and influence during the last decade of the twentieth century with the introduction of computers and the internet to their body of tools. As the relationship between education and technology became more intimate and integrated, this body began to disassociate with teaching duties and became their own positions inside the district structure (Usselman, 2010). In short, they differentiated from their constituent faculty body into a group of people who had no main-line duties in instruction, but instead focused on the standardization of how technology supports instruction. This process and function is exactly what Mintzberg describes as an essential defining element of the technostructure compared to the strategic apex (Mintzberg, 1979).

Herein lies the beginning of the discontinuity in how the position of technology director is perceived. Instead of a formulated position from the view of a Mintzberg structure (or similar conceptual framework), this type of position diversified out of the main-line apex structure through the actions of individuals. That is to say, the position of the technology director transitioned during the late 1990s from a part-teaching and partdirector role into a full-time administration role. This is likely due to the view of the role as a derivative of French's expert power and those individuals treating their expert power as legitimate power influencers instead of any planned role creation (French and Raven, 
1959). Indeed, the one source that directly addresses the role of technology director is the Planning for Technology philosophical work and treats the role as a member of the apex administration (Whitehead, Jensen, Boschee 2013). Therefore, each position had their own evolutionary stance and history at each local institution; at best, the district-todistrict commonality of definition for the codified technostructure that is the technology director is only similar in situations wherein one district copied another district's definition (or had administrators and personal in common).

\section{Monetary Policy}

Monetary policy is the first cornerstone in how a district structures itself to be successful. As noted by Faith Crampton, David Thompson, and Randell Vessely in their 2004 study, discussion of the direct funding of the infrastructure of the district is oftentimes skipped in lieu of discussing overall funding equality of districts themselves. What is done with the money is as important a conversation as having the money itself in order to enact policies that lead to success in education. An important and recurring note in this discussion, however, is how technology is perceived: oftentimes beneficial and pervasive, but even the discussion of the infrastructure itself leaves no mentioning of direction of technology spending.

One of the primary questions of the recent era has been the effectiveness of the inclusion and integration of technology upon a district's plan for meeting the challenges posed by new local, state, and federal standards. Schools have been spending more upon technology with the goal towards developing a new classroom for the 21 st century. However, technology purchases are only a first step in the process of how this integration 
has progressed; a unified plan is important to make certain the money spent has a beneficial effect (Kalmbacher, Maxon 2000).

This is a particularly important question as general research into how money is spent in a district has shown that increasing various funding elements of the overall budget do not strongly equate in general student improvement outside of teacher hiring (Hibner, 2008; Stephens, 2009). Proof of the need of the conversation on spending comes directly from the discussion of how a district's affluence affects upon student academic performance. To put it plainly a more affluent district has much better general student outcomes. For smaller economy district, overcoming the poorer affluency issues becomes paramount as the spending of the resources the smaller district has is a greater element in overcoming any affluence remediation (Dyson, 2009).

Handling the money issue is therefore a significant discussion; however, the impact of technology integration has the impact of exasperating the differences between the wealth divide. The general expenditure of money is not a solution in of itself, but the accurate targeting of technology plans and technology benefits can benefit learning (Moran, Selff, 1999). However, these plans must be focused away from the agendas set by outside forces that have their own agenda goals (Moran, Selff, 1999; Stephens, 2009) and should be directed and researched directly as a function of pedagogy (Moran, Selff, 1999).

\section{School Technology Plans}

An interesting element of this dichotomy between the district administrators and technology directors can be summed up in how the district structures the execution of the 
school's technology plan. Namely, who is responsible for filling out the yearly required technology plan and who fulfills the plan. While DESE does require the district to have a plan and that it meets the Missouri Education Technology Strategic Plan (DESE, 2011), exactly who comes up with the plan is left to the district to determine. There is a very detailed series of timelines, goals, objectives, and plans to fill out (DESE, 2010), but those standards are left to the district to choose who fulfills the legal obligations.

There are two general descriptions I have found on the subject; the first from International Society for Technology in Education (ISTE)'s description of the technology director includes development of the technology plan (ISTE, 2012). However, the pedagogical work by Whitehead, et al, leaves only the implementation of the technology plan to the technology director, with the genesis of the technology plan as an item of the administrative strategic vision for a district (Whitehead, Jensen, Boschee 2013). Exactly who is creating this plan would serve the elocution on the position of the technology director: is the position an advisory technostructure with expert power or is the position viewed as a member of the strategic apex in decision making?

\section{Instructional and Faculty Development Policy}

Developing such a skill set and a technology plan for a district is crucial and critical for success in education (Waterman, 2009; Allen, Seaman 2012). Oddly, the direction of literature in this area is not devoted to technology directors themselves, but to the technology instructor. This is a significant hole in the research; by analogy, this would be akin to judging the speed and quality of one's driving ability without regard to the state of the road or the skills of those who built the road. Indeed, the closest article I 
have found thus has more to do with discussing the likes and discomforts of the instructors and how administration views those trends (Allen, Seaman, 2012) and not the policies or plans that lead (or demark away from) those actions.

Other studies that are close involve professional development views and how technology directors can assist in helping organizations develop those programs for communities and communities of practice, but not the districts they are a part (Bradshaw, 2010). Indeed, this study would be illuminative if it had not focused on just thirteen directors, of which only seven replied. One important dissertation study does outline the need for critically looking at the technology plan component to the overall spending of a district in order to help elocution in discerning a difference between low-spending and high-spending schools, but the question is phrased as follow-through research and not of the question itself (Waterman, 2009).

The one and only exemplar I found in the further readings about how the position of technology director interrelates to the overall district is found in the second edition of Drs. Whitehead, Jensen, and Mr. Boschee's Second Edition of Planning for Technology. This particular book goes into some length as to the relationship of the position as it relates to all other areas of the district in sixteen points across six themes. These themes are leadership and vision, teaching and learning, productivity and professional practice, a theme devoted to the technostructure issues of support, management, and operations. However, this prose is not directly supported by evidence based evaluation; instead, it is a philosophical derivative of those authors interpretation of the International Society for Technology in Education and their Technology Standards for School Administrators as defined in 2011 and 2001 respectively (Whitehead, Jensen, Boschee 2013). 
In short, while there are some philosophies by disparate groups on what a technology director might tell their district or corresponding faculty constitute how they should act, this is from the view of the personage of the technology director themselves from the organizations they may belong. There is little discussion from the administration or district on how the technology director should work with them, or what the skill requirements should be in order to fulfill those duties. At best, there is discussion on how to write a broad technology plan to do items such as "...technology program management will be provided by designated personnel at the school, school district, and state/provincial/regional levels" (ITEEA Standards, 2012). How to do so is left entirely open.

\section{Summary}

The position of the technology director is comparable to Mintzberg's technostructure in his organizational theory. Viewing the position through this lens provides the structure the profession historically and currently lacks in developing maturity and vision for the future of the profession. However, the measurements of what is expected and understood how the position is currently ill-defined; therefore, a baseline needs to be established. This study is an attempt to examine the current state of the view of the profession, in order to establish that very baseline for the future maturation and matriculation of the profession. 


\section{Chapter III: Design and Methodology}

The purpose of this study is to explore the school district's administrators' views on the position of the technology director. For this study, I will explore how the position is viewed by both administrators and the technology directors themselves, what skills are considered critical, and how the position interrelates with instruction at a district. The baseline view of the secondary education administrator will be compared against how the elementary school education administrator, the middle school administrator, and the technology directors all view the position.

Primarily this study is intended as a basis for curriculum review and development. Once the relative strengths are assessed, skill needs identified, and position of the current technology directorship is identified among the population serving Missouri districts are all identified, the means of elocution on how to improve the process of establishing a standard for education is an uncomplicated means of definition. Therefore, reviewing the modern curriculum to ensure the population is getting the treatment effect to move the technology directors into the skillsets the various districts need for development becomes a matter of refinement and education, instead of one of definition and direction. In short, everyone will come to consensus for moving forward in the development of the field and the requirements by which the position of technology director can be assessed.

\section{Purpose}

The purpose of this inquiry study is to discover how district school administrators perceive the directorship skills needed for a successful technology director in Missouri. At this stage in the research, the skill needs will be defined as technological proficiencies, curriculum understanding design proficiencies, and the understanding on fitting both the 
previous skill sets to form solid growth plans for their districts. This is to see how the directorship is seen through the lenses of a technical developer and through the lenses as an instructional designer; in other words, as a nuts and bolts technician and/or as a person who is responsible for helping the faculty of a district effectively use the systems that the district has built. One point in this discussion would be an analysis of how money has affected this view through looking at how the relative wealth factor of a district should help control or examine that effect.

\section{Research Questions}

1. How does an elementary school building administrator's perception of the role of technology director compare to perception of the secondary school building administrator?

- There is no difference between the elementary school building administrator's perception of the role of the technology director and the secondary school building administrator's view.

2. How does a middle school building administrator's perception of the role of technology director compare to perception of the secondary school building administrator?

- There is no difference between the middle school building administrator's perception of the role of the technology director and the secondary school building administrator's view.

3. How does a secondary school building administrator's perception of the role of technology director compare to perception of the technology director? 
- There is no difference between the technology director's perception of the role of the technology director and the secondary school building administrator's view.

\section{Design for the Study}

The focus of this study will be survey driven. District administrators and technology directors will be surveyed. Administrators will be surveyed for their perceptions on the role of technology directorship. Technology directors will also be surveyed for their perspective on their role. Do these administrators and technology directors have a view consistent with Mintzberg's view of the technostructure and the overall organization (Mintzberg, 1979 )? Do these groups view the issue of legitimate and expert power in the same context as defined by French and Raven (French and Raven, 1959)?

The target in the qualitative portion of the survey is to bring forth the themes of the position of technology director is viewed by both the administrators and technology directors themselves. The quantitative section is a Likert scale assessment of the skills currently taught in the local service area's university's technology director master's program. The use of the quantitative questions will evaluate if a common ground currently exists to promote the unification of the ideal of the requirements to what a technology director is and does in their profession. Bringing both together should provide illuminative elocution of the state of the education technology director, and perhaps bound the future direction of perception of how the role needs to change and what skills are needed for the role. 


\section{Population and Participants}

The population being surveyed in this study is exactly and only the administrator(s) of a district and their technology director(s). This includes the superintendents and the principals who form the executive decision-making and policymaking members of a district. These are the specific people who answer to their district school boards, to Missouri, and to the federal officials charged with the affairs of education. This population, therefore, defines who they need to fulfill the role of the technology director and the skills needed for their district to develop and thrive. It is this group, therefore, whose view of the position needs to be surveyed in order to establish the baseline of what the profession should and does offer. This is the very definition baseline that needs to be established, in order to further research into the profession overall.

For this study, the focus will be entirely based on the service area for a Missouri university; a more comprehensive study of the entire state belongs rightly to the Missouri Department of Elementary and Secondary Education (DESE) and the Missouri Department of Higher Education (DHE). The reason is simple and straightforward: this author has access and prior relationships to the two departments who offer master-level programs that provide elements of the skills in question to the public. Since the membership of the technology directorship is also related to the service area, developing the quantitative part of the tool for the study would be easier to derive from those local resources.

Participants will be contacted via mail and email harvested from the DESE website with an introduction to the survey that include the reasons behind the study, an 
informed consent form should they fill out the survey, and the actual survey itself. The initial contacting messages will cross-refer to both versions, so that the participants can choose which method best fits their response style to finish.

\section{Data Collection and Instrumentation}

The constructivism worldview best matches the assumptions I will apply to data collection and data analysis. According to Creswell (2009) "Constructivists hold assumptions that individuals seek understanding of the world in which they live and work." The study of how technology directorship itself works is a constructivist act inside the view of an action research project. I understand how personal experiences will affect the data coding during the qualitative examination, so the focus will be on the participants' interpretation of the questions themselves, not of my held belief.

Since it is unknown if the administrators' view themselves are is independent from both administrators (elementary versus secondary, etc.) as well as their view compared to that of the technology directors, an analysis of how those views do or do not interrelate needs to calculated. For this purpose, a chi-squared analysis will show if there is a treatment effect between the different types of administrators and of the position itself. Simply put, the analysis will show if the administrator view on technology directorship is related to what kind of administrator as well as determining if the technology director themselves are deviant from the overall administrator view.

The expected total population of this survey is around three hundred administrators in the aforementioned service region. The survey itself is currently unvalidated; therefore the survey will be first sent to a sample of around thirty 
administrators and technology directors. From this sample, the generalizability of the survey will be established by generating an estimate through the use of Cronbach's alpha.

The study is a survey; one part qualitative, one part quantitative. The qualitative part is to be used to establish the flavor and deep goals for the profession, whereas the quantitative part is to address how defined skills help (or are profession neutral) accomplish the goals of the profession. In order to achieve consistency, the survey will be one single tool that goes to all participants. Since the qualitative element of the survey is meant to explore each participant's full personal view on the role of the technology director in a more in-depth level than each individual's view on the importance of each type of activity a technology director may do, this element is considered secondary to the quantitative assessment. The qualitative element is specifically meant to provide a broader perspective to enrich the understanding of the participant perspectives of the root of the research questions: just how is the role perceived? For this reason, the concurrent embedded strategy as outlined by John Creswell's Research Design is the basis to the survey tool outline, this allows the study to garner two levels of data simultaneously (Creswell, 2009); both the deep inner conceptualization of the survey subject's view of the role, and a quantitative review of the common activities the role of technology director..

An established data collection process includes setting the study boundaries, establishing the questionnaire survey, and collecting data through a survey (Creswell, 2009). The participants will choose between the paper and electronic method of filling out the survey. However, all returned paper copies of the survey will be entered into the main electronic storage file for data processing during the data analysis stage. The 
overall data storage file will contain the results from both the qualitative portion and the quantitative portion. A Chi-Square test of independence provides the analysis for the quantitative data collected for this research. The survey instrument will use a Likert series of questions combined with some open ended questions, see Appendix B.

\section{Human Subjects Protection}

As a part of the survey package itself, the human subjects informed consent form will be included as well as an introduction to the study itself. An example consent form can be found in Appendix A that will be available to each participant for approval before they complete the survey. The digital version sent via email will have a link to the consent form; the consent form itself will forward the electronic participant to the actual online survey instrument. The survey itself will contain no district identifying material in either form, other than the demographic questions that ask the size of the district and the relative wealth of the district. For the digital storage portion, an anonymity process will be followed as outlined in the following subsection. The envelopes for the physical returns will be destroyed, leaving only the surveys themselves; this should likewise ensure anonymity for those who choose the physical method of response.

\section{Anonymous storage.}

I have direct access to the server that will be used for the electronic form for the survey. As a part of the anonymity process and due to the access levels, the following steps will be followed. First, the form itself will not store the IP addresses of the respondents. Since the subjects of the survey are members of a school district, and both 
the physical and electronic copies of the survey are going to their school district addresses, it follows to be reasonable that the participants will answer from their offices. Due to how public schools in Missouri gain internet access, their office computers are uniquely identifiable in every action online; the form therefore must not know exactly from where each response originates, nor store that for later use.

Second, the Internet Information Service logs for this site will be cleared at the end of the survey. Since the researcher has full access to the server in question, and all internet transactions will store the addresses of every action that occurs on the server, clearing those $\operatorname{logs}$ is an essential set of steps to ensure the researcher is unaware of the exact origin of any response. These two actions should provide an excellent assurance of complete anonymity to any respondent who answers electronically.

\section{Role of Researcher and Bias}

I am deeply concerned with the state of technology directorship in general, as well as the state of skill levels, ethics, and reliability of the instructional technology service community as a whole to education. I have also been involved with the two departments at a university who are attempting to deal with the concept of technology management and educational technology. I believe the results from this study can help establish a baseline that furthers both the research into the subject and provides us with a vision of where the issues stand now as a way to create curriculum to address technology directorship certification at that university. 


\section{Limitations}

While the question of money is being directly addressed, the question of determination cannot be directly measured. For an example, this author was involved with a small school in the service area of question during the early to middle 1990s, helping a district who had a technology director who did not have a basic understanding of how networking worked, but was very dedicated and acted through several challenges left unaddressed by other institutions. To put this in perspective, this school was one of the first to deliver their yearbook electronically (both during the years in question and overall in history) to their publisher in Missouri when their primary challenge was rain. The room set aside for the yearbook class leaked during rainstorms (and for several hours thereafter); because of this, the director, yearbook advisor, and students all planned their deadlines around the rainy season and rainy days. They were successful in achieving their technology goals despite both relative per capita and absolute monetary and knowledge disadvantages by simply being determined and moving forward in adapting to their situation. Since evaluative criteria are limited to the realms of knowledge base and skills assessment, the supportive areas of determination and grit must sadly remain unmeasured and in the arena of the toughness and spirit of the public school faculty and staff. In short, exceptional determination is an unmeasurable quantity in a discussion of skill or monetary policy.

Another limitation will be the size of the population examined. I am limited as to the scale of where in Missouri that can be easily addressed by programs that attend Southeast Missouri, not to mention the manpower that would be required to handle all 473 districts currently active in Missouri. For this reason, the focus of the study is 
limited to the service area of an university in the southern part of the state, and not to the broader area of Missouri itself.

Finally, the last known limitation the author has about the study is the actual technological literacy that the administrators themselves express. Administrators are skilled and informed policy makers, but they themselves are rarely technology experts; they are policy and pedagogical experts due to experience and history. For example, a district administrator may find that the school needs need a distance program to reach students who are biologically incapable of attending school. The administrator then has to decide among several technologies to accomplish this goal; these include webinars, online classes, interactive television, and a few other solutions. Each of these solutions requires a different skill set, but similar pedagogical skills; however, which skillset and environment to set up is a question of which skills the technology director has, not of the need itself. So, part of what bounds what the administrator will chose is their assessment of what is available; this in of itself is usually the result of what their technology director informs them is possible with a given problem. This directly influences what the administrator sees as needed skills.

\section{Assumptions}

The first assumption derives from a requirement from the Missouri Department of Elementary and Secondary Education (DESE), namely that every district has a technology plan that addresses several key questions about how the district uses technology (DESE, 2013). This assumption centers around that the plan is well-known 
by the administrator, is supported by the administrator, is well-understood by the administrator, and is not simply a paperwork hurdle that is updated once a year.

The second assumption is that there is a person or collection of people that the administrator appoints to carry out this technology plan. The person with primary responsibility for these actions is the technology directors. In smaller schools this may be a part time position for one individual; for the larger schools, this may be a small staff of people.

The third assumption is that the administrator has a mental framework for what these workers should do and how they do it. This is where the mental framework of the administrator starts playing a major effect upon the questions: those skills may be purely based in the technician side of technology, or those skills may also involve what is traditionally attributed to instructional design with the tools that are already there. Examination of this view is at the core of the study.

The fourth assumption is tied to how the questions will act and the knowledge base the administrator themselves have over how they have mentally defined the position. Namely, while I expect fairly enlightening answers to the qualitative questions of the study, the skill survey towards the end of the questionnaire might exist outside the administrators' comfort level in answering. This may affect how they answered the questions in the qualitative part, as the very act of asking about a proficiency currently not considered at a district may well impact the end answers to the qualitative section. 


\section{Summary}

The position of technology director in public school districts is not well-defined. The views on what makes a good technology director are also varied. In order to determine how the profession should be evaluated, and how to improve the profession, a baseline understanding of how the profession is viewed needs establishment. With that baseline, new and existing programs can be developed or modified at universities to help mature the profession by providing the credentials and skills needed for the members of the profession and the districts they serve. 


\section{Chapter IV: Findings and Results}

\section{Introduction}

This study inquires into what skills district school administrators view necessary for district technology directors in Missouri, focusing on the Southeast Missouri quadrant of the state. Part of the hypothesis of this examination included comparing the different kinds of school administrators to see if there was a difference in how the position of the Technology Director was perceived. The null hypothesis was that all types of school or building administrators would have a unified view of the necessary skills to be a technology director by looking at the required skills through the lens of a technology manager and instructional designer, given that the role touched on both technology and instructional content.

Specifically, the technology manager skills tied into how the technostructure focuses on standardizing work inputs and tools; those questions tie into how and if the administrators view the job as a traditional member of what Mintzberg referred to as the technostructure. Similarly, looking at the instructional design questions, questions focused on standardizing the skillset of the main line workforce, focuses the view of if the administrators view the job as a traditional member of the support structure. Finally, asking the questions at the onset about how the position is categorized and later asking about the administrator view of the position. These questions help define where the position is in terms of power and location relative to the strategic apex of the organization.

Originally, this connection was conceived from the literature as originating in the linking assertion that the technology plan for a district links both the technology 
purchased by the district with how the technology is used by the instructional staff therein to the district. By viewing how the district administrators view those relationships, the research was attempting to fix a relative position in regards to how the administrators saw (or if they saw) any administrative power in the position.

The research questions are:

1. How does an elementary school building administrator's perception of the role of technology director compare to perceptions of the secondary school building administrator?

2. How does a middle school building administrator's perception of the role of technology director compare to perceptions of the secondary school building administrator?

3. How does a secondary school building administrator's perception of the role of technology director compare to perceptions of the technology director?

The survey went out to 284 district and building administrators, this included superintendents, primary school building administrators, middle-school building administrators, secondary school administrators, and technology directors (if noted in the DESE database). Of those, thirty-seven responded to the Likert questions, with an additional seven administrators responding only to the open-ended questions. The majority of the respondents were superintendents, comprising seventeen of the total. Those who responded primarily broke down to two groups of schools: smaller rural schools and larger urban schools. 


\section{Findings}

Figure 1: Distribution of Administrators who answered the survey

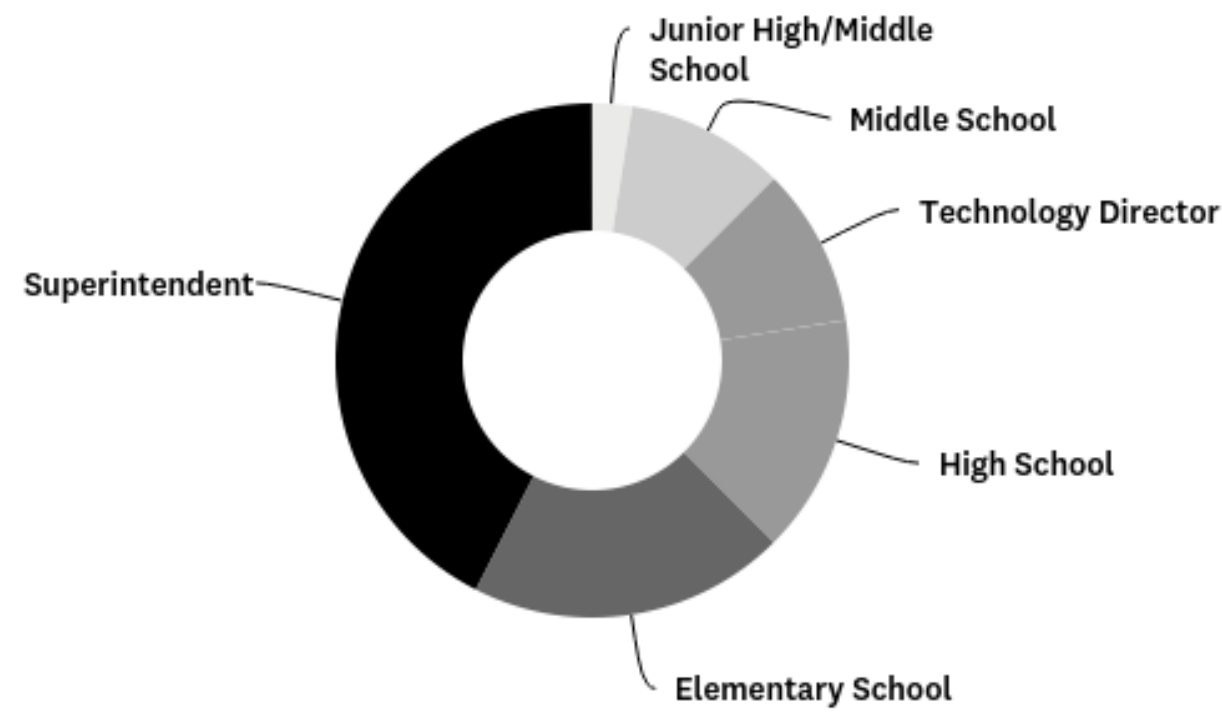

Table 1: Distribution of the Administrators who answered the survey

\begin{tabular}{|c|c|c|}
\hline ANSWER CHOICES & \multicolumn{2}{|c|}{ RESPONSES } \\
\hline Elementary School & $20.00 \%$ & 8 \\
\hline Middle School & $10.00 \%$ & 4 \\
\hline Junior High/Middle School & $2.50 \%$ & 1 \\
\hline High School & $15.00 \%$ & 6 \\
\hline Technology Director & $10.00 \%$ & 4 \\
\hline Superintendent & $42.50 \%$ & 17 \\
\hline TOTAL & & 40 \\
\hline
\end{tabular}


Figure 2: Technology Director Classification

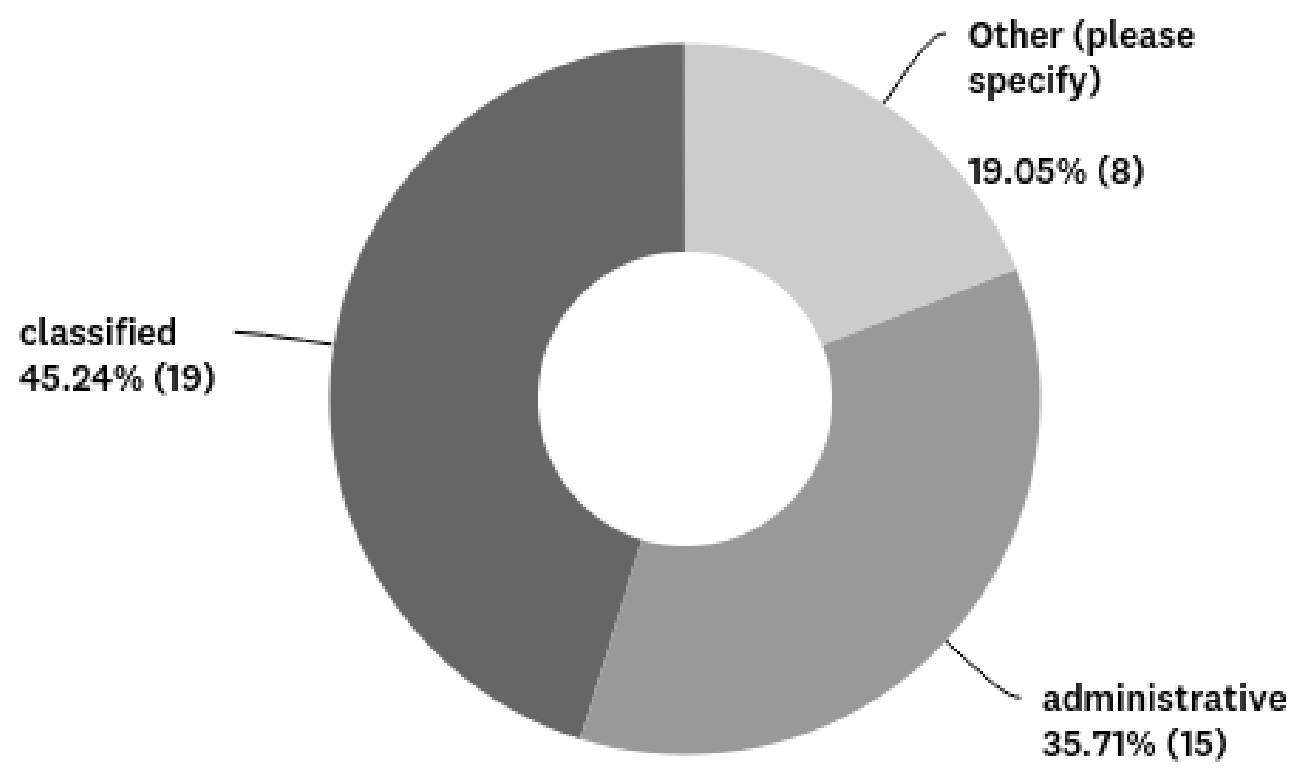

Table 2: Technology Director classification

\begin{tabular}{|c|c|c|}
\hline ANSWER CHOICES & RESPONSES & \\
\hline Other (please specify) & $19.05 \%$ & 8 \\
\hline administrative & $35.71 \%$ & 15 \\
\hline classified & $45.24 \%$ & 19 \\
\hline TOTAL & & 42 \\
\hline
\end{tabular}

First, the breakdown of the respondents is very heavily based in the administrative view of the district superintendent. The single Junior High administrator who responded had answers that matched to the responses the middle school administrators provided, including the comment sections of the survey. However, they were still considered separate groups in the analysis.

Second, the breakdowns of how the position was classified in the district was very interesting in how evenly split the classification was distributed. The qualitative element will be discussed later in this chapter in the qualitative area, but the answers to the 
“other" category broke down into the classification bridging both an administrator's role, and the role of a staff instructor trainer role. Essentially, the other answers broke down into a combination in some sense containing both the administrative and classified role. This question is the beginning point to where this researcher realized the hypotheses may have been framing the wrong research questions. For summative purposes, the broad results for the entire population are in Appendix C. For further discussion later in the chapter, the following are the results of the analysis of the administrators' view on the skills assessments; given the relatively low sample population, this researcher chose a wide $\mathrm{p}$-value to evaluate the null hypothesis.

Table 3: Type of Administrator * Be able to plan a building's network infrastructure

\begin{tabular}{|c|c|c|c|c|c|c|c|}
\hline & & Skipped & $\begin{array}{l}\text { Not } \\
\text { Important } \\
\end{array}$ & $\begin{array}{l}\text { Somewhat } \\
\text { Important }\end{array}$ & Important & $\begin{array}{l}\text { Very } \\
\text { Important } \\
\end{array}$ & Total \\
\hline \multirow{6}{*}{$\begin{array}{l}\text { Type of } \\
\text { Administrator }\end{array}$} & Elementary & 0 & 0 & 0 & 0 & 6 & 6 \\
\hline & Middle & 0 & 0 & 0 & 1 & 3 & 4 \\
\hline & Jnr High & 0 & 0 & 0 & 0 & 1 & 1 \\
\hline & $\begin{array}{l}\text { High/Secondar } \\
\text { y }\end{array}$ & 0 & 0 & 0 & 0 & 4 & 4 \\
\hline & $\begin{array}{l}\text { Technology } \\
\text { Director }\end{array}$ & 0 & 0 & 0 & 0 & 4 & 4 \\
\hline & Superintendent & 0 & 0 & 0 & 2 & 14 & 16 \\
\hline Total & & & 0 & 0 & 3 & 32 & 35 \\
\hline
\end{tabular}

Asymptotic

Significance

\begin{tabular}{lr|r|r} 
& \multicolumn{1}{c}{ Value } & df & \multicolumn{1}{c}{ (2-sided) } \\
\hline Pearson Chi-Square & $3.099^{\mathrm{a}}$ & 5 & .685 \\
\hline Likelihood Ratio & 3.920 & 5 & .561 \\
\hline Linear-by-Linear & .137 & 1 & .711 \\
Association & & & \\
\hline N of Valid Cases & 35 & & \\
\hline
\end{tabular}


There was no significant association between the building level administrators and technology directors and their ability to plan a building's network infrastructure $\mathrm{X}^{2}(5)=.685>.05$

Table 4: Type of Administrator * Be able to set up, design, and develop a classroom learning space.

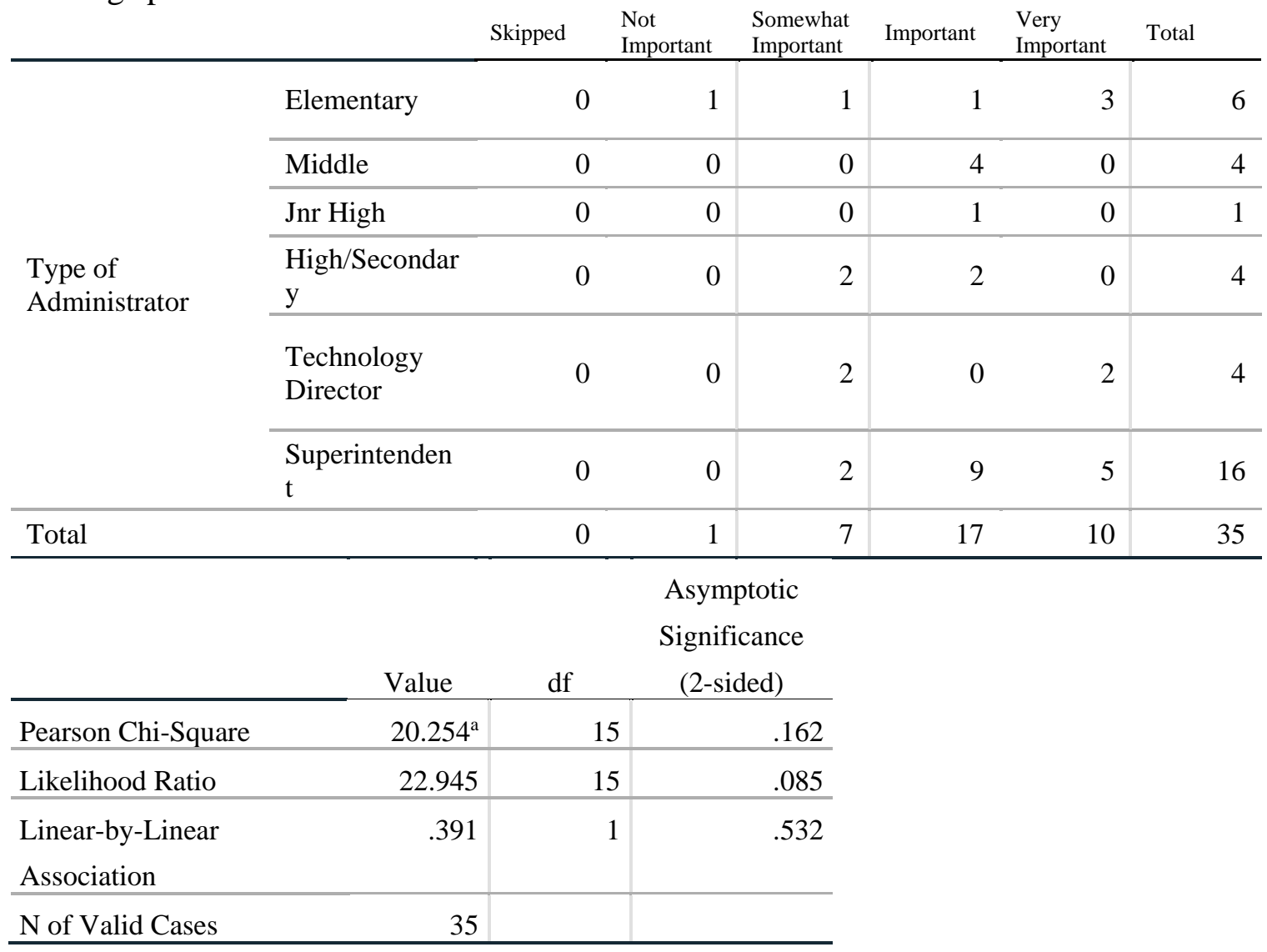

There was no significant association between building level administrators and tech. directors and their ability to be able to set up, design, and develop a classroom learning space.X2(5) $=0.162>.05$. 
Table 5: Type of Administrator * Conduct experiments, analyze data, interpret and apply results to solve problems related to optimizing systems and processes.

\begin{tabular}{|c|c|c|c|c|c|c|c|}
\hline & & Skipped & $\begin{array}{l}\text { Not } \\
\text { Important }\end{array}$ & $\begin{array}{l}\text { Somewhat } \\
\text { Important }\end{array}$ & Important & $\begin{array}{l}\text { Very } \\
\text { Important }\end{array}$ & Total \\
\hline \multirow{6}{*}{$\begin{array}{l}\text { Type of } \\
\text { Administrator }\end{array}$} & Elementary & 0 & 1 & 0 & 4 & 1 & 6 \\
\hline & Middle & 0 & 0 & 0 & 2 & 2 & 4 \\
\hline & Jnr High & 0 & 1 & 0 & 0 & 0 & 1 \\
\hline & $\begin{array}{l}\text { High/Secondar } \\
\mathrm{y}\end{array}$ & 0 & 0 & 0 & 3 & 1 & 4 \\
\hline & $\begin{array}{l}\text { Technology } \\
\text { Director }\end{array}$ & 0 & 0 & 0 & 2 & 2 & 4 \\
\hline & $\begin{array}{l}\text { Superintenden } \\
\mathrm{t}\end{array}$ & 0 & 0 & 2 & 8 & 6 & 16 \\
\hline Total & & 0 & 2 & 2 & 19 & 12 & 35 \\
\hline
\end{tabular}

Asymptotic

Significance

\begin{tabular}{lrrrr} 
& \multicolumn{1}{c}{ Value } & \multicolumn{1}{c}{ df } & \multicolumn{1}{c}{ (2-sided) } \\
\hline Pearson Chi-Square & $23.512^{\mathrm{a}}$ & 15 & .074 \\
\hline Likelihood Ratio & 14.625 & 15 & .479 \\
\hline Linear-by-Linear & 1.061 & 1 & .303 \\
Association & & & \\
\hline N of Valid Cases & 35 & & \\
\hline
\end{tabular}

There was no significant association between the building level administrators and technology directors and their ability to conduct experiments, analyze data, interpret and apply results to solve problems related to optimizing systems and processes $\mathrm{X}^{2}(5)=$ $.074>.05$. This value is close to a value that would lead to the rejection of the null hypothesis; this is discussed later. 
Table 6: Type of Administrator * Prioritize and project maintenance, sustainability, and growth costs.

\begin{tabular}{|c|c|c|c|c|c|c|c|}
\hline & & Skipped & $\begin{array}{l}\text { Not } \\
\text { Important }\end{array}$ & $\begin{array}{l}\text { Somewhat } \\
\text { Important }\end{array}$ & Important & $\begin{array}{l}\text { Very } \\
\text { Important }\end{array}$ & Total \\
\hline \multirow{6}{*}{$\begin{array}{l}\text { Type of } \\
\text { Administrator }\end{array}$} & Elementary & 0 & 0 & 0 & 3 & 3 & 6 \\
\hline & Middle & 0 & 0 & 0 & 2 & 2 & 4 \\
\hline & Jnr High & 0 & 0 & 0 & 0 & 1 & 1 \\
\hline & $\begin{array}{l}\text { High/Secondar } \\
\mathrm{y}\end{array}$ & 0 & 0 & 0 & 2 & 2 & 4 \\
\hline & $\begin{array}{l}\text { Technology } \\
\text { Director }\end{array}$ & 0 & 0 & 0 & 1 & 3 & 4 \\
\hline & $\begin{array}{l}\text { Superintenden } \\
t\end{array}$ & 0 & 1 & 0 & 2 & 13 & 16 \\
\hline Total & & 0 & 1 & 0 & 10 & 24 & 35 \\
\hline
\end{tabular}

Asymptotic

Significance (2-

\begin{tabular}{lrrrr} 
& \multicolumn{1}{c}{ Value } & \multicolumn{1}{c}{ df } & \multicolumn{1}{c}{ sided $)$} \\
\hline Pearson Chi-Square & $6.435^{\mathrm{a}}$ & 10 & .777 \\
\hline Likelihood Ratio & 7.108 & 10 & .715 \\
\hline $\begin{array}{l}\text { Linear-by-Linear } \\
\text { Association }\end{array}$ & .501 & 1 & .479 \\
\hline N of Valid Cases & & & \\
\hline
\end{tabular}

There was no significant association between the building level administrators and technology directors and their ability to prioritize and project maintenance, sustainability, and growth costs. $\mathrm{X}^{2}(5)=.777>.05$. 
Table 7: Type of Administrator * Create and maintain a replacement cycle for software and hardware resources.

\begin{tabular}{|c|c|c|c|c|c|c|c|}
\hline & & Skipped & $\begin{array}{l}\text { Not } \\
\text { Important }\end{array}$ & $\begin{array}{l}\text { Somewhat } \\
\text { Important }\end{array}$ & Important & $\begin{array}{l}\text { Very } \\
\text { Important }\end{array}$ & Total \\
\hline \multirow{6}{*}{$\begin{array}{l}\text { Type of } \\
\text { Administrator }\end{array}$} & Elementary & 0 & 0 & 0 & 4 & 2 & 6 \\
\hline & Middle & 0 & 0 & 0 & 1 & 3 & 4 \\
\hline & Jnr High & 0 & 0 & 0 & 0 & 1 & 1 \\
\hline & $\begin{array}{l}\text { High/Secondar } \\
\mathrm{y}\end{array}$ & 0 & 0 & 0 & 2 & 2 & 4 \\
\hline & $\begin{array}{l}\text { Technology } \\
\text { Director }\end{array}$ & 0 & 0 & 0 & 1 & 3 & 4 \\
\hline & $\begin{array}{l}\text { Superintenden } \\
\mathrm{t}\end{array}$ & 0 & 0 & 2 & 2 & 12 & 16 \\
\hline Total & & 0 & 0 & 2 & 10 & 23 & 35 \\
\hline
\end{tabular}

Asymptotic

\begin{tabular}{lrrrr} 
& \multicolumn{2}{c}{} & \multicolumn{2}{c}{$\begin{array}{c}\text { Significance } \\
\text { (2-sided) }\end{array}$} \\
\hline Pearson Chi-Square & $9.435^{\mathrm{a}}$ & 10 & .491 \\
\hline Likelihood Ratio & 10.097 & 10 & .432 \\
\hline Linear-by-Linear & .424 & 1 & .515 \\
Association & & & \\
\hline N of Valid Cases & 35 & & \\
\hline
\end{tabular}

There was no significant association between the building level administrators and technology directors and their ability to prioritize and project maintenance, sustainability, and growth costs. $\mathrm{X}^{2}(5)=.491>.05$. 
Table 8: Type of Administrator * Configure routers to use routing protocols in a network topology.

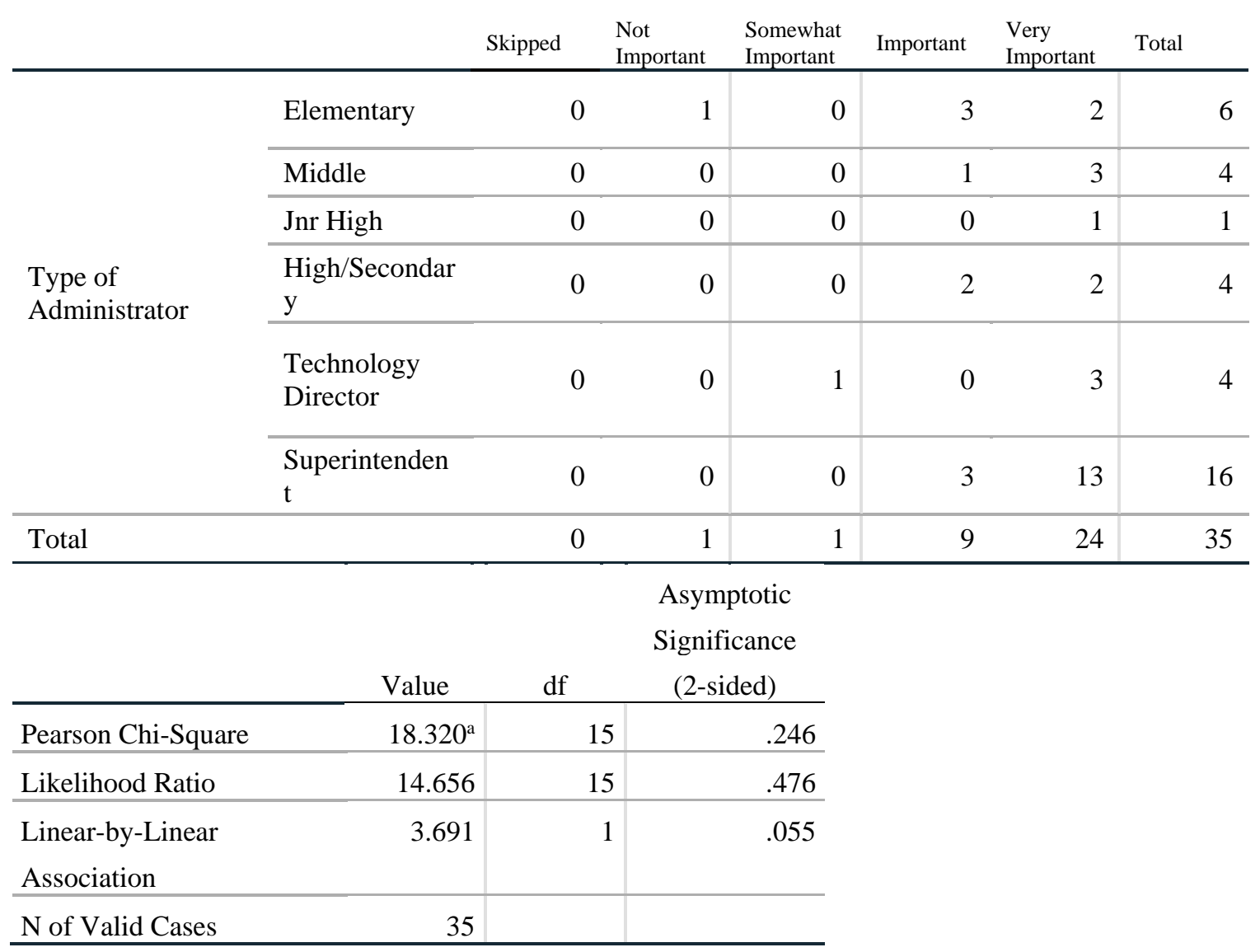

There was no significant association between the building level administrators and technology directors and their ability to configure routers to use routing protocols in a network topology. $\mathrm{X}^{2}(5)=.246>.05$. 
Table 9: Type of Administrator * Articulate issues concerning ethics for building computer resources

\begin{tabular}{|c|c|c|c|c|c|c|c|}
\hline & & & $\begin{array}{l}\text { Not } \\
\text { Important }\end{array}$ & $\begin{array}{l}\text { Somewhat } \\
\text { Important }\end{array}$ & Important & $\begin{array}{l}\text { Very } \\
\text { Important }\end{array}$ & Total \\
\hline \multirow{6}{*}{$\begin{array}{l}\text { Type of } \\
\text { Administrator }\end{array}$} & Elementary & 0 & 0 & 0 & 3 & 3 & 6 \\
\hline & Middle & 0 & 0 & 0 & 2 & 2 & 4 \\
\hline & Jnr High & 0 & 0 & 0 & 0 & 1 & 1 \\
\hline & $\begin{array}{l}\text { High/Secondar } \\
\mathrm{y}\end{array}$ & 0 & 0 & 0 & 2 & 2 & 4 \\
\hline & $\begin{array}{l}\text { Technology } \\
\text { Director }\end{array}$ & 0 & 0 & 0 & 1 & 3 & 4 \\
\hline & $\begin{array}{l}\text { Superintenden } \\
\mathrm{t}\end{array}$ & 0 & 0 & 1 & 7 & 8 & 16 \\
\hline \multirow[t]{2}{*}{ Total } & & 0 & 0 & 1 & 15 & 19 & 35 \\
\hline & \multicolumn{6}{|c|}{$\begin{array}{l}\text { Significance } \\
\text { (2-sided) }\end{array}$} & \\
\hline Pearson Chi-Square & $2.886^{\mathrm{a}}$ & 10 & & .984 & & & \\
\hline Likelihood Ratio & 3.628 & 10 & & .963 & & & \\
\hline $\begin{array}{l}\text { Linear-by-Linear } \\
\text { Association }\end{array}$ & .061 & 1 & 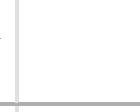 & .804 & & & \\
\hline $\mathrm{N}$ of Valid Cases & 35 & & & & & & \\
\hline
\end{tabular}

There was no significant association between the building level administrators and technology directors and their ability to articulate issues concerning ethics for building computer resources. $\mathrm{X}^{2}(5)=.984>.05$. 
Table 10: Type of Administrator * Articulate issues concerning security personal safety for district computer resources.

\begin{tabular}{|c|c|c|c|c|c|c|c|}
\hline & & Skipped & $\begin{array}{l}\text { Not } \\
\text { Important }\end{array}$ & $\begin{array}{l}\text { Somewhat } \\
\text { Important }\end{array}$ & Important & $\begin{array}{l}\text { Very } \\
\text { Important } \\
\end{array}$ & Total \\
\hline \multirow{6}{*}{$\begin{array}{l}\text { Type of } \\
\text { Administrator }\end{array}$} & Elementary & 0 & 0 & 2 & 2 & 2 & 6 \\
\hline & Middle & 0 & 0 & 0 & 2 & 2 & 4 \\
\hline & Jnr High & 0 & 0 & 0 & 1 & 0 & 1 \\
\hline & $\begin{array}{l}\text { High/Secondar } \\
\text { y }\end{array}$ & 0 & 0 & 0 & 1 & 3 & 4 \\
\hline & $\begin{array}{l}\text { Technology } \\
\text { Director }\end{array}$ & 0 & 0 & 0 & 0 & 4 & 4 \\
\hline & $\begin{array}{l}\text { Superintenden } \\
\mathrm{t}\end{array}$ & 0 & 0 & 0 & 2 & 14 & 16 \\
\hline Total & & 0 & 0 & 2 & 8 & 25 & 35 \\
\hline
\end{tabular}

Asymptotic

\begin{tabular}{lrrrr} 
& Value & df & \multicolumn{2}{c}{$\begin{array}{c}\text { Significance } \\
\text { (2-sided) }\end{array}$} \\
\hline Pearson Chi-Square & $18.754^{\mathrm{a}}$ & 10 & .043 \\
\hline Likelihood Ratio & 16.603 & 10 & .084 \\
\hline $\begin{array}{l}\text { Linear-by-Linear } \\
\text { Association }\end{array}$ & 10.208 & 1 & .001 \\
\hline N of Valid Cases & & & \\
\hline
\end{tabular}

There was a significant association between the building level administrators and technology directors and their ability to articulate issues concerning security personal safety for district computer resources. $\mathrm{X}^{2}(5)=.043<.05$.

This is the one question in the skills survey with a significant difference in how the administrators view the skill. Note that the Superintendent values verses the other administrators is the heavy element of this distinction; this researcher questions if the relative numbers of each population had an outsized affect upon the results. 
Table 11: Type of Administrator * Articulate issues concerning copyright and acceptable use for district computer resources.

\begin{tabular}{|c|c|c|c|c|c|c|c|}
\hline & & Skipped & $\begin{array}{l}\text { Not } \\
\text { Important }\end{array}$ & $\begin{array}{l}\text { Somewhat } \\
\text { Important }\end{array}$ & Important & $\begin{array}{l}\text { Very } \\
\text { Important }\end{array}$ & Total \\
\hline \multirow{6}{*}{$\begin{array}{l}\text { Type of } \\
\text { Administrator }\end{array}$} & Elementary & 0 & 0 & 3 & 2 & 1 & 6 \\
\hline & Middle & 0 & 0 & 0 & 3 & 1 & 4 \\
\hline & Jnr High & 0 & 0 & 0 & 1 & 0 & 1 \\
\hline & $\begin{array}{l}\text { High/Secondar } \\
\mathrm{y}\end{array}$ & 0 & 0 & 0 & 3 & 1 & 4 \\
\hline & $\begin{array}{l}\text { Technology } \\
\text { Director }\end{array}$ & 0 & 0 & 0 & 2 & 2 & 4 \\
\hline & $\begin{array}{l}\text { Superintenden } \\
\mathrm{t}\end{array}$ & 0 & 0 & 4 & 3 & 9 & 16 \\
\hline Total & & 0 & 0 & 7 & 14 & 14 & 35 \\
\hline
\end{tabular}

Asymptotic

\begin{tabular}{|c|c|c|c|}
\hline & Value & df & $\begin{array}{l}\text { Significance } \\
\text { (2-sided) }\end{array}$ \\
\hline Pearson Chi-Square & $13.646^{\mathrm{a}}$ & 10 & .190 \\
\hline Likelihood Ratio & 15.674 & 10 & .109 \\
\hline $\begin{array}{l}\text { Linear-by-Linear } \\
\text { Association }\end{array}$ & 2.559 & 1 & .110 \\
\hline $\mathrm{N}$ of Valid Cases & 35 & & \\
\hline
\end{tabular}

There was no significant association between the building level administrators and technology directors and their ability to articulate issues concerning copyright and acceptable use for district computer resources. $X^{2}(5)=.190>.05$. 
Table 12: Type of Administrator * Develop internet or computer based instructional modules.

\begin{tabular}{|c|c|c|c|c|c|c|c|}
\hline & & Skipped & $\begin{array}{l}\text { Not } \\
\text { Important }\end{array}$ & $\begin{array}{l}\text { Somewhat } \\
\text { Important }\end{array}$ & Important & $\begin{array}{l}\text { Very } \\
\text { Important }\end{array}$ & Total \\
\hline \multirow{6}{*}{$\begin{array}{l}\text { Type of } \\
\text { Administrator }\end{array}$} & Elementary & 0 & 2 & 2 & 1 & 1 & 6 \\
\hline & Middle & 0 & 1 & 1 & 1 & 1 & 4 \\
\hline & Jnr High & 0 & 0 & 0 & 1 & 0 & 1 \\
\hline & High/Secondary & 0 & 0 & 3 & 1 & 0 & 4 \\
\hline & $\begin{array}{l}\text { Technology } \\
\text { Director }\end{array}$ & 0 & 1 & 0 & 1 & 2 & 4 \\
\hline & Superintendent & 1 & 1 & 4 & 6 & 4 & 16 \\
\hline Total & & 1 & 5 & 10 & 11 & 8 & 35 \\
\hline
\end{tabular}

Asymptotic

\begin{tabular}{lr|r|r} 
& \multicolumn{3}{c}{ Significance (2- } \\
& \multicolumn{1}{c}{ Value } & df & \multicolumn{1}{c}{ sided) } \\
\hline Pearson Chi-Square & $14.205^{\mathrm{a}}$ & 20 & .820 \\
\hline Likelihood Ratio & 15.800 & 20 & .729 \\
\hline $\begin{array}{l}\text { Linear-by-Linear } \\
\text { Association }\end{array}$ & 1.014 & 1 & .314 \\
\hline N of Valid Cases & & & \\
\hline
\end{tabular}

There was no significant association between the building level administrators and technology directors and their ability to develop internet or computer based instructional modules. $\mathrm{X}^{2}(5)=.820>.05$. 
Table 13: Create multimedia presentations (audio podcasts, video podcasts, and similar presentation) for use in educational settings.

\begin{tabular}{|c|c|c|c|c|c|c|c|}
\hline & & Skipped & $\begin{array}{l}\text { Not } \\
\text { Important }\end{array}$ & $\begin{array}{l}\text { Somewhat } \\
\text { Important }\end{array}$ & Important & $\begin{array}{l}\text { Very } \\
\text { Important } \\
\end{array}$ & Total \\
\hline \multirow{6}{*}{$\begin{array}{l}\text { Type of } \\
\text { Administrator }\end{array}$} & Elementary & 0 & 2 & 2 & 2 & 0 & 6 \\
\hline & Middle & 0 & 3 & 0 & 1 & 0 & 4 \\
\hline & Jnr High & 0 & 0 & 0 & 0 & 1 & 1 \\
\hline & $\begin{array}{l}\text { High/Secondar } \\
\text { y }\end{array}$ & 0 & 0 & 3 & 1 & 0 & 4 \\
\hline & $\begin{array}{l}\text { Technology } \\
\text { Director }\end{array}$ & 0 & 1 & 0 & 2 & 1 & 4 \\
\hline & $\begin{array}{l}\text { Superintenden } \\
t\end{array}$ & 0 & 2 & 5 & 7 & 2 & 16 \\
\hline Total & & 0 & 8 & 10 & 13 & 4 & 35 \\
\hline
\end{tabular}

Asymptotic

Significance (2-

\begin{tabular}{lrrrr} 
& \multicolumn{1}{c}{ Value } & \multicolumn{1}{c}{ df } & \multicolumn{1}{c}{ sided) } \\
\hline Pearson Chi-Square & $22.829^{\mathrm{a}}$ & 15 & .088 \\
\hline Likelihood Ratio & 21.434 & 15 & .124 \\
\hline $\begin{array}{l}\text { Linear-by-Linear } \\
\text { Association }\end{array}$ & 2.988 & 1 & .084 \\
\hline N of Valid Cases & & & \\
\hline
\end{tabular}

There was no significant association between the building level administrators and technology directors and their ability to create multimedia presentations (audio podcasts, video podcasts, and similar presentation) for use in educational settings. $\mathrm{X}^{2}(5)$ $=.088>.05$. This is another skill that will be discussed in the implications part of the study. 
Table 14: Type of Administrator * Create an individual professional development plan to increase teacher instructional technology skills.

\begin{tabular}{|c|c|c|c|c|c|c|c|c|}
\hline & & & & rtant & $\begin{array}{l}\text { Somewhat } \\
\text { Important }\end{array}$ & Important & $\begin{array}{l}\text { Very } \\
\text { Important }\end{array}$ & Total \\
\hline \multirow{6}{*}{$\begin{array}{l}\text { Type of } \\
\text { Administrat } \\
\text { or }\end{array}$} & Elementary & 0 & & 1 & 2 & 2 & 1 & 6 \\
\hline & Middle & 0 & & 1 & 1 & 1 & 1 & 4 \\
\hline & Jnr High & 0 & & 0 & 0 & 0 & 1 & 1 \\
\hline & High/Secondary & 0 & & 0 & 2 & 2 & 0 & 4 \\
\hline & $\begin{array}{l}\text { Technology } \\
\text { Director }\end{array}$ & 1 & & 1 & 0 & 1 & 1 & 4 \\
\hline & Superintendent & 2 & & 2 & 3 & 7 & 2 & 16 \\
\hline \multirow[t]{2}{*}{ Total } & & 3 & & 5 & 8 & 13 & 6 & 35 \\
\hline & \multicolumn{8}{|c|}{$\begin{array}{l}\text { Asymptotic } \\
\text { Significance } \\
\text { (2-sided) }\end{array}$} \\
\hline Pearson Chi-Square & $13.355^{\mathrm{a}}$ & & 20 & & .862 & & & \\
\hline Likelihood Ratio & 14.475 & & 20 & & .806 & & & \\
\hline $\begin{array}{l}\text { Linear-by-Linear } \\
\text { Association }\end{array}$ & .380 & & 1 & & .538 & & & \\
\hline $\mathrm{N}$ of Valid Cases & 35 & & & & & & & \\
\hline
\end{tabular}

There was no significant association between the building level administrators and technology directors and their ability to create an individual professional development plan to increase teacher instructional technology skills. $\mathrm{X}^{2}(5)=.862>.05$. 
Table 15: Type of Administrator * Analyze current issues and trends in educational technology.

\begin{tabular}{|c|c|c|c|c|c|c|c|}
\hline & & Skipped & $\begin{array}{l}\text { Not } \\
\text { Important }\end{array}$ & $\begin{array}{l}\text { Somewhat } \\
\text { Important }\end{array}$ & Important & $\begin{array}{l}\text { Very } \\
\text { Important }\end{array}$ & Total \\
\hline \multirow{6}{*}{$\begin{array}{l}\text { Type of } \\
\text { Administrator }\end{array}$} & Elementary & 0 & 1 & 2 & 2 & 1 & 6 \\
\hline & Middle & 0 & 0 & 0 & 3 & 1 & 4 \\
\hline & Jnr High & 0 & 0 & 0 & 0 & 1 & 1 \\
\hline & $\begin{array}{l}\text { High/Secondar } \\
\text { y }\end{array}$ & 0 & 0 & 0 & 2 & 2 & 4 \\
\hline & $\begin{array}{l}\text { Technology } \\
\text { Director }\end{array}$ & 0 & 0 & 1 & 1 & 2 & 4 \\
\hline & $\begin{array}{l}\text { Superintenden } \\
t\end{array}$ & 0 & 0 & 1 & 8 & 7 & 16 \\
\hline \multirow[t]{2}{*}{ Total } & & 0 & 1 & 4 & 16 & 14 & 35 \\
\hline & Value & df & \multicolumn{2}{|c|}{ Significance } & & & \\
\hline Pearson Chi-Square & $13.464^{\mathrm{a}}$ & 15 & & .567 & & & \\
\hline Likelihood Ratio & 12.641 & 15 & & .630 & & & \\
\hline $\begin{array}{l}\text { Linear-by-Linear } \\
\text { Association }\end{array}$ & 3.540 & 1 & 1 & .060 & & & \\
\hline $\mathrm{N}$ of Valid Cases & 35 & & & & & & \\
\hline
\end{tabular}

There was no significant association between the building level administrators and technology directors and their ability to analyze current issues and trends in educational technology. $X^{2}(5)=.567>.05$. 
Table 16: Type of Administrator * Develop a building technology plan for teaching and learning.

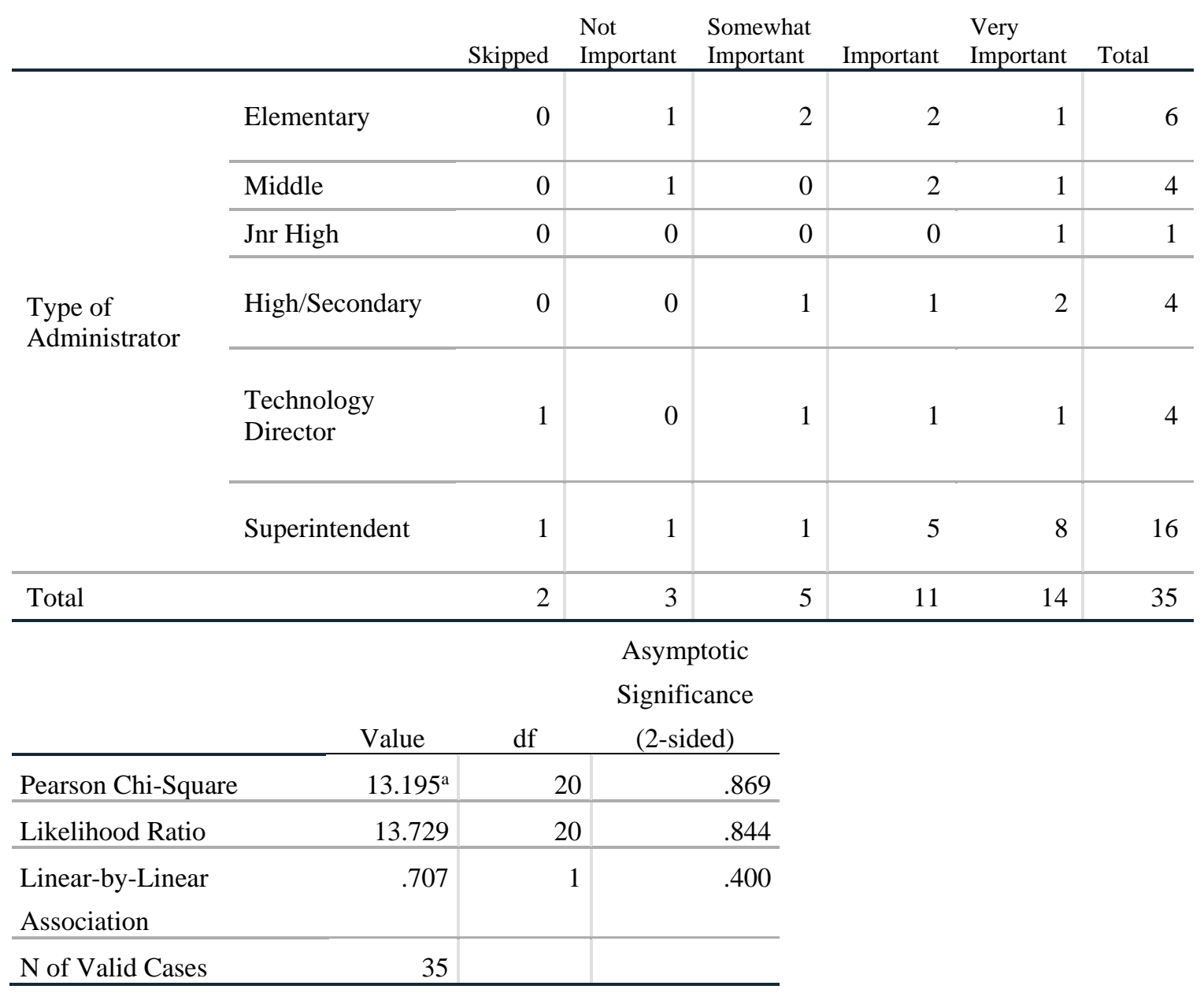

There was no significant association between the building level administrators and technology directors and their ability to develop a building technology plan for teaching and learning. $\mathrm{X}^{2}(5)=.869>.05$. 
Table 17: Type of Administrator * The Technology Director's role is the function of his or her expertise.

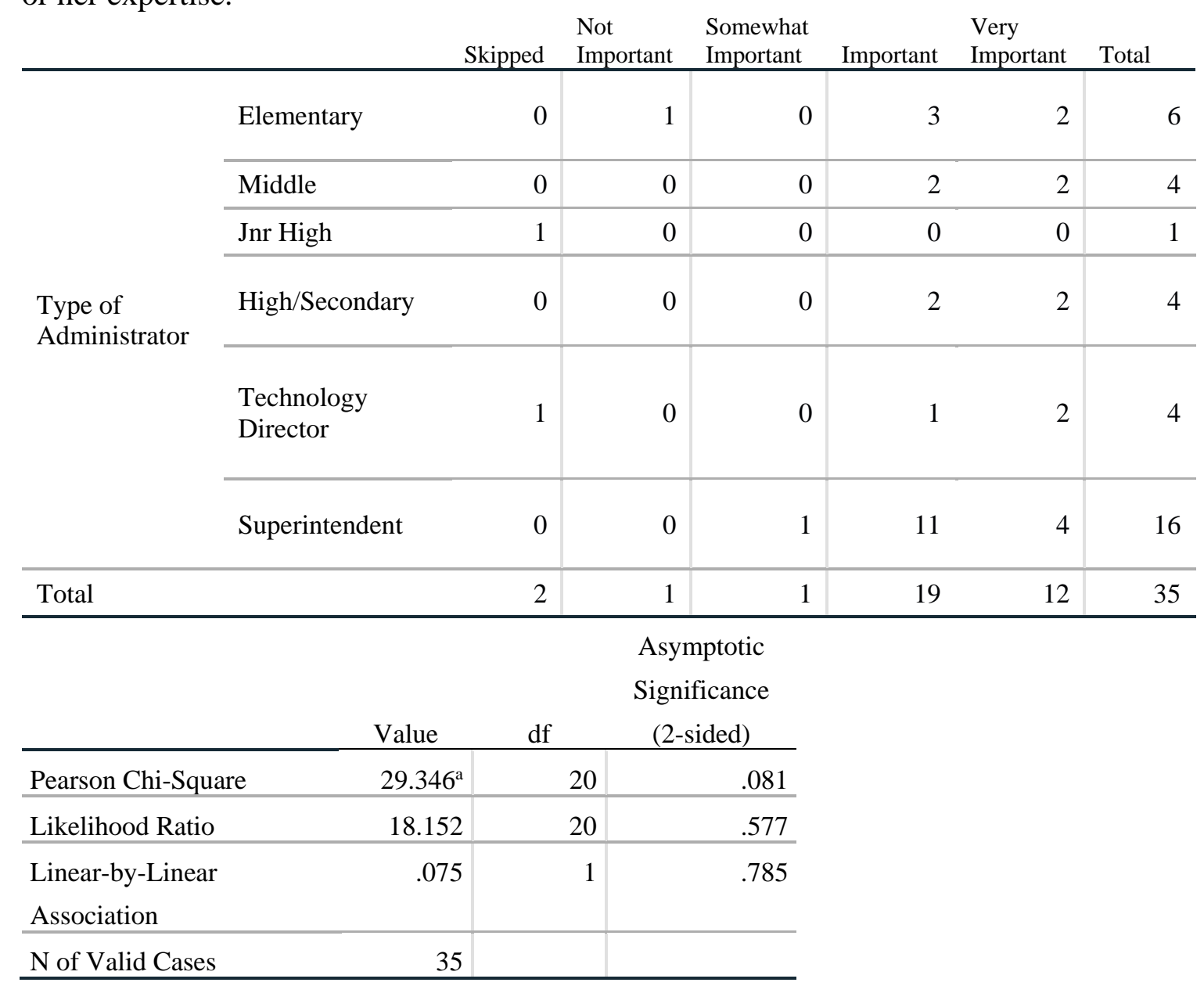

There was no significant association between the building level administrators and technology directors and if the Technology Director's role is the function of his or her expertise. $\mathrm{X}^{2}(5)=.081>.05$.

This is an interesting break in the survey, as this question is not about skills or sets of skills, but more about how the power of the position is derived. Again, is this a position of French and Raven's expert power? Note that the two skipped responses are a technology director and the junior high administrator; in the latter case, this is the only time the administrator varied away from the middle school supervisors. 
Table 18: Type of Administrator* The Technology Director's role is the function of his or her position in the district.

\begin{tabular}{|c|c|c|c|c|c|c|c|}
\hline & & Skipped & $\begin{array}{l}\text { Not } \\
\text { Important }\end{array}$ & $\begin{array}{l}\text { Somewhat } \\
\text { Important }\end{array}$ & Important & $\begin{array}{l}\text { Very } \\
\text { Important }\end{array}$ & Total \\
\hline \multirow{6}{*}{$\begin{array}{l}\text { Type of } \\
\text { Administrator }\end{array}$} & Elementary & 0 & 0 & 1 & 1 & 4 & 6 \\
\hline & Middle & 0 & 0 & 0 & 2 & 2 & 4 \\
\hline & Jnr High & 1 & 0 & 0 & 0 & 0 & 1 \\
\hline & High/Secondary & 0 & 0 & 0 & 3 & 1 & 4 \\
\hline & $\begin{array}{l}\text { Technology } \\
\text { Director }\end{array}$ & 1 & 0 & 0 & 1 & 2 & 4 \\
\hline & Superintendent & 0 & 1 & 1 & 8 & 6 & 16 \\
\hline Total & & 2 & 1 & 2 & 15 & 15 & 35 \\
\hline
\end{tabular}

Asymptotic

Significance

\begin{tabular}{lr|r|r} 
& \multicolumn{1}{c}{ Value } & \multicolumn{1}{c}{ df } & \multicolumn{1}{c}{ (2-sided) } \\
\hline Pearson Chi-Square & $27.684^{\mathrm{a}}$ & 20 & .117 \\
\hline Likelihood Ratio & 18.123 & 20 & .579 \\
\hline $\begin{array}{l}\text { Linear-by-Linear } \\
\text { Association }\end{array}$ & .257 & 1 & .612 \\
\hline N of Valid Cases & & & \\
\hline
\end{tabular}

There was no significant association between the building level administrators and technology directors and if the Technology Director's role is the function of his or her position in the district. $\mathrm{X}^{2}(5)=.117>.05$.

The question of power also derives from the strategic apex: is this position seen as a position with legitimate power inside the organization as opposed to being seen as a position that is the result of a skillset? Note, on the question of the source of power in both of the last two questions, there exists variation that almost breaks the null 
hypothesis. The implications of this is an issue of further research that will be discussed in Chapter 5.

\section{Results}

The qualitative aspects of the survey varied greatly in the verbosity of respondents. Some responded with one word answers, such as "budget" (during the position role question) and "vital" (during the question about the role the Technology director plays in the creation of the district's technology plan) to an eloquent job description summation one would find on a job search site. Overall, the answers broke into two basic themes: that of a small, rural school's view, and that of a larger, urban school's view. Indeed, the scope of the job changed radically when comparing the size of the school districts to their various responses. This is not what this researcher originally theorized would be the case; the literature review various articles have a flavor and tendency to mention specific technologies (both software and hardware) to solve different problems that a building in a district would face with little to no continuity of one technology to more than one situation. This lead to the theory that either the needs were unified, or varied according to the type of administrator. This is exactly the view that this data argues against as will be discussed later in the chapter.

The Technology Director, was described as "supportive," "teacher/Liberian," "is administrative as well as the technician," and importantly "contracted service." Among the larger schools, this answer broke down to responses like "not sure," "teacher," "support staff," and "mixture of administrative and technician." Specifically, the descriptions varied not by the size of the school, but by the number of people hired to do the technology work for the district. While this varied with the size of the school, one of 
the smaller, poorer schools responded with results on staffing nearly identical as the larger schools. This is a significant point to one assumption previously unmentioned, and will be discussed later.

Overall, the smaller the school, the more likely the descriptions became singular, and talked about very specific roles. These roles included "budget," "basic admin duties," "multitude of jobs for him such as: budget, maintenance, safe guards, etc.," and "report to the Superintendent, take care of technology plan, request technology budget, oversee technology implementation." Specifically the view of the role is beginning to take form: one person to solve every situation, with whatever organizational power needed therein. That is to say, the Technology Director is given whatever administrative power perceived by the strategic apex to make all the decisions. This is a point for discussion in the next chapter.

The larger the school district, the more likely the descriptions covered a larger subject term, with descriptions that the role had the power to do "purchasing, outside technology hiring, district wide decision making," "budget oversight, delegation of duties, evaluation," and "train staff, purchase." One respondent had a very eloquent "no" as an answer to this question; discussion on this will continue into the next chapter.

\section{How is the role of the Technology Director seen by administrators?}

One very common theme that came forth from this question is richly described as "important" and "needed in every building." The overall sense from all of the responses is that a very few districts have enough staff to meet the needs of the instructional aspects of the school. One non-Technology Director distinct administrator's statement crystalizes what many of the responses seemed to be hinting at: 
The Director should have a vast awareness of infrastructure, software, mechanics, etc. The district should have a separate facilitator whose job is to incorporate technology into instruction. I don't believe it is possible for one person to do both in an exceptional capacity.

This factor of splitting the view of the work the job entails varies with the number of staff a district has employed (full time or part time). The view of increased instructional results increased with the size of the technologist staff; all but a handful of the respondents had at most one full-time staff member, with about half of those doubledipping to other jobs (librarian, teacher, and administrator) in the district. The more staff that the district had, however, the more complete the discussion became over the training, discussion, and communication elements of the valued skills. However, this increase did not come directly with district wealth, but with the number of staff hired. The oddity of the result in the staff does not come from the school size, it comes from the school districts themselves and what they provisioned; there is no unifying element this researcher found as to why those districts who have the larger staffs have those staffs including wealth or number of full-time instructors in the district.

Theme 1: Needed in every building as technical support.

One of the respondents responded with exactly the statement "they are needed in every building." Of note, this was also one of three districts that did not report having a technology director in the district, but not one of the two that reported contracting the position out to a third party vendor. This particular respondent noted that they only had a single full-time technician and that this person was responsible for all the purchasing and maintenance, but not the planning, of the district's technology plan. 
All other respondents who wrote a reply to this question noted a need, primarily focusing on statements such as "keep all technology updated and working 24/7," several "important" responses, and variations on the theme of overseeing all technology resources in a district. In short, statements like "he is (the) part of the district team that develops and implements the plan," are common. The more likely a district was to be both small and have a single staff member serving as the Technology Director (with one case where this person is "only" a technician), the more often this person was referred to as having a direct service relationship to every instructional staff member. An exemplar quote to address this subject is:

"In our small district, they assist the administration in making technology goals, assist the teaching staff in implementing technology in the classroom, and provide for onsite technology needs of the district."

This particular quote leads to the next most common theme, training. Both in the sense of the Technology Director directly serving as the direct trainer of the instructional staff and as the supporter to those efforts.

Theme 2: Train and support (learning) needs.

The next most common theme amongst the respondents to this question focused on the need of the Technology Director to lead the training aspects of the use of the various technologies employed by the district. Of note, these responses seemed to focus on the operation of said technologies (both hardware and software), and not the pedagogical use of said items. Essentially, the opinions focused on the first level of use, that of straight operation and not the "how best to use" level of control and mastery to the instructional staffs. 
Concisely, quotes such as "introduce new forms of technology to the district," and, importantly, "Our technology director works on the hardware and software side of technology... instruction is driven by teachers," note the mainstay of these responses. Only a single response notes a shift from this kind of element with a statement of "... more and more an increased role in utilization vs. installation." This, combined with the values on the instructional designed flavored survey questions, caused this researcher to reevaluate part of the survey itself; this will be discussed later in the chapter.

Theme 3: Skill mastery and communication are key.

Every written response had an element of concern over the importance of the role, many continued onward to express how thorough the skillset of the Technology Director had to be to function, and roughly half of the written responses contained a variation of communication and collaboration with the instructional staff. This communication has to do with how the district plan is implemented, and the plan's refinement, than the normal technology support or trouble shooting aspects.

One important notion for the next chapter comes in the form of how each Technology Director is expected to self-educate in a contiguous manner throughout their career in a constant effort:

The Technology Director is responsible for smooth operation of the district technology, technology services, and school computer networks. The Technology Director must acquire and update skills as necessary for effective network management and technology integration into classroom instruction. The director installs, troubleshoots, and maintains hardware and software; trains users in 
applications on the network; coordinates activities of outside vendors, consultants, and trainers.

This element is hinted at by many of the other responses in how each mentions the sole responsibility of the Technology Director to be the "owner" of not just the technology plan, but of all the implementation therein as well as the direct communication of each of these aspects to every stakeholder inside and outside the district.

\section{Description of the role the Technology Director plays in the district technology plan?}

Theme 1: Lynchpin

Every written response to this question involved variations on a theme, primarily either using phrases such as "lynchpin," "important," or leader when referring to someone in the district when the district has only the Technology Director and no other technology staff member. For those with larger staffs, phrases such as "responsible," "support," and the "...long range planner," show up often. On the rare occasion the Technology Director is not seen as the owner or originator of the district plan, he or she is still seen as "...imperative to the success of the district technology plan" as a "...part of the district team that develops and implements the plan."

Three of the districts had responses that indicated that there was either (in one case) no Technology Director, or that (in the case of two districts) this position was contracted out to a person or company that serviced more than one district. Of note, in the case of the contracted out cases, it does not appear as these two districts use the same service. They are both separated by considerable distance (counties away from each other), and one refers to a single person whereas the other refers to a company. But, all 
three of these districts views the services of the position as critical. Further research needs to be done on these cases to determine if this type of scenario is the result of economics or some other factor such as the availability of skilled staff.

Theme 2: Collaborate with stakeholders versus ownership

There is general unification on the value, or relative lack, of the skillsets that comprise the research topic as assessed by this survey, there is some variation. A surprising variation that also requires follow-up research is that of the view of the role when there are supporting staff members to the role itself. As the staff size increased, including the districts which only had student support to the role of the Technology Director, the themes of "ownership" of the technology plan shifted. These discussions became more about the technology director, staff, and support personnel collaborating and supporting the instructional staff than unilateral planning and execution. With the larger staffs, the administrators start using phrases such as "the district team" and "...serve in the role as advisor to the superintendent and the technology committee" to convey the importance of the instructional stakeholders in the system, in the stead of being the sole fountain of wisdom on the subject.

In summation, the role is considered important and critical to the district plan and the implementation of the plan, but there exists variation in how the plan comes into being. This variation does not have an obvious link to the size of the district once the district has at least one full-time staff member, but the way the answers to the survey themselves exist has an apparent link to if the district Technology Director has at least one subordinate member (part time or full time) as reported earlier in the survey. 


\section{Discussion}

Prior to the analysis portion of this study, this researcher had an unconscious basis that needs examination and discussion. Primarily the researcher viewed the research topic, and wrote the survey accordingly, from the lens of perceiving the likely skills that a Technology Director needed would be the result of either managing technology or as an aspect of the traditional instructional design elements. Specifically, when looking at skill training, pedagogical use of the various technologies, and instructional support actions, the administrators did not see those skills as important as the standardization of the workflow support actions.

Reviewing the frame of how the instructional design questions were added to the survey, a refinement on both how the instructional design questions and the technology management questions came into play. Specifically, the first, second, and sixth questions all apply to how resources are set up and used as an action. The third and thirteenth questions apply to the skill of the Technology Director in how they research new topics and managed the district's use of technology. The fourth, fifth, and fourteenth questions all apply to how the planning takes form. The seventh, eighth, and ninth questions all apply to policy development. Moreover the tenth, eleventh, and twelfth questions all apply to instructional action capacity normally handled by instructional designers. Considering the data from this point of view, results in the following analysis:

Table 19: ANOVA of type of Variance of Administrators upon Recoded Skillsets ANOVA

\begin{tabular}{|c|c|c|c|c|c|c|}
\hline & & 7i & & & & \\
\hline & & Sum of & & & & \\
\hline & & Squares & $\mathrm{df}$ & Mean Square & $\mathrm{F}$ & Sig. \\
\hline Resource management & Between & .456 & 5 & .091 & .709 & .622 \\
\hline & Groups & & & & & \\
\hline
\end{tabular}




\begin{tabular}{|c|c|c|c|c|c|c|}
\hline & $\begin{array}{l}\text { Within } \\
\text { Groups }\end{array}$ & 3.600 & 28 & .129 & & \\
\hline & Total & 4.056 & 33 & & & \\
\hline \multirow[t]{5}{*}{ Research } & Between & 2.767 & 5 & .553 & 1.719 & .162 \\
\hline & Groups & & & & & \\
\hline & Within & 9.333 & 29 & .322 & & \\
\hline & Groups & & & & & \\
\hline & Total & 12.100 & 34 & & & \\
\hline \multirow[t]{5}{*}{ Planning } & Between & 1.057 & 5 & .211 & .780 & .572 \\
\hline & Groups & & & & & \\
\hline & Within & 7.863 & 29 & .271 & & \\
\hline & Groups & & & & & \\
\hline & Total & 8.921 & 34 & & & \\
\hline \multirow[t]{5}{*}{ Policy/Training } & Between & 1.454 & 5 & .291 & 1.285 & .297 \\
\hline & Groups & & & & & \\
\hline & Within & 6.565 & 29 & .226 & & \\
\hline & Groups & & & & & \\
\hline & Total & 8.019 & 34 & & & \\
\hline \multirow[t]{5}{*}{ Instruction Design } & Between & 2.318 & 5 & .464 & .579 & .716 \\
\hline & Groups & & & & & \\
\hline & Within & 23.225 & 29 & .801 & & \\
\hline & Groups & & & & & \\
\hline & Total & 25.543 & 34 & & & \\
\hline
\end{tabular}

Specifically, looking at these values, this researcher is becoming convinced that there is not a difference in how the administrators view the types of skillsets the position of Technology Director employs. Research management is moderately to strongly unified in how powerful the different types of administrators view the skill with an Fscore of 0.709 ; and they consider it also moderately to strongly significant with a significance score of 0.622 . Planning is seen similarly with similar values: these two sets of skills administrators see as a moderate to strong influence on the success of the job. This is contrasted with the F-scores above 1 for both the research and training aspects of the job; the groups are very unified (strongly unified) in their opinion that those skillsets 
are not important with both skillsets coming in below 0.300 in significance. The view of the baseline instructional design skillset is significant (with a score of .716), but only moderately unified with a value of 0.579 .

To put it bluntly, their views on these skillsets are quite unified, and there exists a near rejection that the elements of research and the traditional instructional design components are a needed skillset for a Technology Director in comparison to the functional basic computer and networking skills. Indeed, the only question that was skipped by the primary non-technology director respondents was one of the instructional design questions, where a single respondent then went on to type at length in the latter qualitative elements of the survey (as well as answering the rest of the Likert portion of the survey). The main element that keeps the rejection from being complete are the cases of the schools with the larger staff (including the district which a large staff that is also not a particularly large or rich district); these specific districts are the respondents that place high values on the needs of the more traditional instructional design skillsets. Specifically looking at exactly how the district administrators view those six skills that relate to the instructional design component results in the following analysis:

Table 20: Analysis of variance of administrators and instructional design skills.

\begin{tabular}{|c|c|c|c|c|c|c|}
\hline & & $\begin{array}{l}\text { Sum of } \\
\text { Squares }\end{array}$ & $d f$ & $\begin{array}{l}\text { Mean } \\
\text { Square }\end{array}$ & $\mathrm{F}$ & Sig. \\
\hline \multirow{3}{*}{$\begin{array}{l}\text { Articulate issues } \\
\text { concerning ethics } \\
\text { for building } \\
\text { computer } \\
\text { resources. }\end{array}$} & $\begin{array}{l}\text { Between } \\
\text { Groups }\end{array}$ & 0.555 & 5 & 0.111 & 0.316 & 0.899 \\
\hline & $\begin{array}{l}\text { Within } \\
\text { Groups }\end{array}$ & 10.187 & 29 & 0.351 & & \\
\hline & Total & 10.743 & 34 & & & \\
\hline $\begin{array}{l}\text { Articulate issues } \\
\text { concerning security }\end{array}$ & $\begin{array}{l}\text { Between } \\
\text { Groups }\end{array}$ & 4.386 & 5 & 0.877 & 3.392 & 0.016 \\
\hline
\end{tabular}




\begin{tabular}{|c|c|c|c|c|c|c|}
\hline \multirow{2}{*}{$\begin{array}{l}\text { personal safety for } \\
\text { district computer } \\
\text { resources. }\end{array}$} & $\begin{array}{l}\text { Within } \\
\text { Groups }\end{array}$ & 7.5 & 29 & 0.259 & & \\
\hline & Total & 11.886 & 34 & & & \\
\hline \multirow{3}{*}{$\begin{array}{l}\text { Articulate issues } \\
\text { concerning } \\
\text { copyright and } \\
\text { acceptable use for } \\
\text { district computer } \\
\text { resources. }\end{array}$} & $\begin{array}{l}\text { Between } \\
\text { Groups }\end{array}$ & 2.329 & 5 & 0.466 & 0.782 & 0.571 \\
\hline & $\begin{array}{l}\text { Within } \\
\text { Groups }\end{array}$ & 17.271 & 29 & 0.596 & & \\
\hline & Total & 19.6 & 34 & & & \\
\hline \multirow{3}{*}{$\begin{array}{l}\text { Develop internet or } \\
\text { computer based } \\
\text { instructional } \\
\text { modules. }\end{array}$} & $\begin{array}{l}\text { Between } \\
\text { Groups }\end{array}$ & 2.551 & 5 & 0.51 & 0.389 & 0.852 \\
\hline & $\begin{array}{l}\text { Within } \\
\text { Groups }\end{array}$ & 38.021 & 29 & 1.311 & & \\
\hline & Total & 40.571 & 34 & & & \\
\hline \multirow{3}{*}{$\begin{array}{l}\text { Create multimedia } \\
\text { presentations } \\
\text { (audio podcasts, } \\
\text { video podcasts, } \\
\text { and similar } \\
\text { presentation) for } \\
\text { use in educational } \\
\text { settings. }\end{array}$} & $\begin{array}{l}\text { Between } \\
\text { Groups }\end{array}$ & 7.734 & 5 & 1.547 & 1.836 & 0.137 \\
\hline & $\begin{array}{l}\text { Within } \\
\text { Groups }\end{array}$ & 24.437 & 29 & 0.843 & & \\
\hline & Total & 32.171 & 34 & & & \\
\hline \multirow{3}{*}{$\begin{array}{l}\text { Create an } \\
\text { individual } \\
\text { professional } \\
\text { development plan } \\
\text { to increase teacher } \\
\text { instructional } \\
\text { technology skills. }\end{array}$} & $\begin{array}{l}\text { Between } \\
\text { Groups }\end{array}$ & 3.463 & 5 & 0.693 & 0.447 & 0.812 \\
\hline & $\begin{array}{l}\text { Within } \\
\text { Groups }\end{array}$ & 44.938 & 29 & 1.55 & & \\
\hline & Total & 48.4 & 34 & & & \\
\hline
\end{tabular}

Articulation of ethical use of resources comes in strong with a significance of 0.899, but the view between the different types of administrators is not unified with a Fvalue of 0.316 . Of the three articulation skills, copyright issues comes in with a moderately strong F value, and a moderate significance. Similarly, developing modules and developing a plan to increase an instructor's skills, the more active production skill activity, comes in with a moderate significance, but a low agreement on how unified the value of the skillset is seen by the administrators. The one skill that nearly every respondent agreed upon with a F-value of 1.836 was how creating multimedia 
presentations was not needed with a significance score of 0.137 . This is paired with how dismally that articulation of security and personal safety is seen, this skill comes in as very unified with a F-value over three, but that view has a significance of 0.016 .

This look into the data distribution, taken in conjunction with the data from earlier in the chapter over how the research elements are perceived in the qualitative segment, the district administrators seem to view that the needed skills for a Technology Director are directly the result of what this researcher has begun to think of "the basic survival needs of the district plan, in the regards to specifically and only the technology infrastructure." The view of the Technology Director being assessed as only the person to serve the basic survival elements of the district's technology plan is in contrast to how their written responses emphasize training, direction, communication/cooperation, and implementation is valued as equal to the mechanical skills. Since both sets of data result from the same population, there is much more to be discussed, considered, and researched. The topic of the next chapter discusses these implications in particular, including the implications of the previously unknown bias in the researcher.

\section{Summary}

The three research questions in this survey break down to the null hypothesis that there is no difference in how the different types of administrators view the job.

The first research question guiding the study reviews how an elementary school building administrator's perception of the role of the technology director compare to the perceptions of the secondary school building administrator? A review of the quantitative data demonstrates that there is no difference in the perceptions of the elementary school 
administrator's and secondary school administrator's view. The review of the qualitative elements also shows there is no difference in how the elementary school administrators and secondary school administrators view the position of the technology director.

The second research question guiding the study reviews how a middle school building administrator's perception of the role of the technology director compare to the perceptions of the secondary school building administrator? A review of the quantitative data demonstrates that there is no difference in the perceptions of the middle school administrator's and secondary school administrator's view. The review of the qualitative elements also shows there is no difference in how the middle school administrators and secondary school administrators view the position of the technology director.

The third research question guiding the study reviews how the technology director's perception of the role of the technology director compare to the perceptions of the secondary school building administrator? A review of the quantitative data demonstrates that there is no difference in the perceptions of the technology director's and secondary school administrator's view. The review of the qualitative elements also shows there is no difference in how the technology directors and secondary school administrator's view the position of the technology director. 


\section{Chapter V: Conclusions, Implications, and Recommendations. Study questions and hypotheses}

As stated previously, the literature review states that district technology directors have an important role in today's school districts (Jackobs, 2010), and that is supported by the direct results of the survey. How this role is perceived by the various types of district administrators, and what skills those administrators view as necessary for a successful Technology Director is the subject of this study. This study is limited to the study of those administrators in the Southeast part of Missouri, and to the differences in how the different administrators of the districts view the position.

Specifically, using Mintzberg's organizational theory, this study attempted to place the position of the role relative to strategic apex as a member of either the technostructure or support structure (Mintzberg, 1979). Essentially asking if the role of a technology director standardizes work outputs or standardizes work skills while also asking if the different kinds of administrators view the position differently. This leads to another assumption, that the role itself is not a member of the strategic apex; but, since it touches every level of an organization, belongs to either of the two supporting structures in a traditional Mintzberg structure, that of support or of the technostructure.

\section{Conclusions}

Over all, the administrators view the skills in either a fairly unified or greatly unified manner in that they see the role as providing a baseline technology infrastructure to support their instructional initiatives at a school. Those specific skills, however, need a further and more in-depth review than this survey provided. This researcher originally envisioned the question as a matter of organizing the role of the district technology 
director into one of two spheres as described by Mintzberg in his work on organizational theory (Mintzberg, 1979). While there are some aspects of the frame that fit, another concept also formed in the analysis of the survey as presented to the sample population: does a hierarchy of technological needs for a school need to be developed? Such a levelled hierarchy should provide an elocution on the skillset needed for a school district to survive and develop in much the same way as Maslow's Hierarchy provides a framework for discussion of an individual's developmental needs.

Second, most of the administrators put the role of the technology director directly into the strategic apex of their organizations. A few put the position in the more advisory role of either the technostructure or support frame, but those are schools that have the larger staff availabilities. Of note, once the district gets a full time staff member, it is not the wealth of the district that seems to be the relevant deciding factor; one of the districts with the most technology staff is a district with modest means. More research into the decision and budgetary process needs to be considered when hiring technology staff and the district itself.

A sub-conclusion to this trend is the need to research the possibility that the role and positions themselves are out of place in the traditional organizational structure; as well as the possibility that those positions need to have their power relationships reconsidered in how they operate in the normal functioning of their various districts.

A follow-up and third conclusion to this line of research results in the current perception of the administrators that the position itself has skills that are more in line with standardizing work outputs and not that of standardizing skills in how they measure the jobs. This is in contradiction with the stated goals that they want or say the job fulfills; 
this contradiction leads directly to the want of a super powered individual to do both roles simultaneously, but primarily evaluating the role on one half of those results specifically. Further definition and research is needed, possibly in conjunction with the needs hierarchy to determine a theory based framework in how to evaluate the disjunction in function of how the job fits into the modern school district. The schools with the broader numbers in their technology support structure are already evolving to this concept in how their administrators discuss the role. However this throws a limitation on the smaller schools that consider the technology director to be not only the sole owner of the technology plan, but the sole keeper and sustainer of the policies and physical elements of the technologies used in the district. Again, further research needs to be done on the treatment affect that the leadership type of those individuals have on the organizations themselves as they now stand. In general, however, the trend of the skills that are valued by the administrators put the position firmly within the technostructure, with elements of the support structure as part of the vision of the role.

Lastly, money and how size is measured are not as important as the staffing element itself. This is seemingly inconsistent with normal theory on how organizations develop and maintain themselves, and maybe the unique result of the maturation cycle of not only how the position of technology directorship is viewed, but the history behind the positions themselves. Further work and research should be done into how money, size of the organization, and staffing sizes needs to be accomplished, especially in the timeframe of continual development and stated importance of the field. 


\section{Implications}

The implications are threefold. Certification, education, and degree validation needs a stronger definition. There is a need for certain baseline skills, but which skills beyond the basic networking topology seem to be at variation depending on the district in question. At best, the descriptions involve concepts of whatever each organization perceives it needs; but the selection is in large part up to a single individual. Only a few of the organizations have feedback from the stakeholders in the system to the one who is making all the decisions, the technology director. This means either the technology director has to have a mastery of the field akin that summates to a master's degree, or a considerable rework of how the technologies are selected need some revision. The interesting commentary that has gone mostly untouched by the majority of the surveyed population is that this is without current regard to pedagogy or curriculum theory knowledge sets. Again, the skills that are valued by the administrators are specifically those that solve a technological issue, and not the broader consideration of educational theory. In the cases were an administrator or current/former teacher fills the role, this need is satisfied by their other educational histories. However, the role itself does not have that element in the needs category, and if the profession is to continue, a revision of both the technology proficiencies and the education theory proficiencies needs to be accomplished... after a basic skills hierarchy is established. In short, both the skills and educational theory knowledge sets need standardization, publication, review, and research.

Second, as currently reviewed, the position of the technology director has elements of the strategic apex of the main core of an organization as well as the 
technostructure and support staff elements. To be precise, that gives the position several elements of power that is not normally allowed in the traditional organizational theory as outlined by Mintzberg and other theorists. The implication herein may well mean that the role and position is having an outsized relationship with their respective organizations for the good or ill of those organizations. The stress that the current active scenario does not match the frameworks and observations of how organizations thrive over time as researched upon during the last century of organizational theory. This needs further examination as to either revisit the theory work, or to rework those positions in to more traditional relative power relationships with the rest of the organization, not to mention researching the equity and policy decision questions inherent to this system.

Third, whilst the stated goals for the position involve skills treatments by the technology director, the skills primarily observed as important or very important belong to the part of an organization that primarily deal with output standardization. That is either a flaw in the tool itself on what kinds of skills are important, or a flaw in the understanding of how the position is to function inside the organization theory itself. Both need further research and expansion, with the possible societal adjustment on the later, or tool replacement on the former.

\section{Future recommendations for research}

This researcher has five research recommendations and two policy action recommendations for the near future in consideration of the results of this study thus far. All five of the purely research options require further study and refinement, primarily by thesis or dissertation level consideration. 
First, the survival needs of a school in relationship to size of instructional staff, size of student body, and size of technology support staff needs to be established. This should lead to toe formation of a hierarchical theory of needs that can describe survival, and various improvement/flourishing states of existence for districts.

Second, district plans across those same districts need to be broadly compared, dissected, and elements considered for how those factors affect the schools in regards to the size of the instructional staff, size of the school body, and the size of the technology support staff.

Third, qualitative research needs to be done, exploring the leadership styles of the technology directors, to see how those leadership elements have affected the organizations in which they occupy a significant position of power. This researcher suggests a review of Peter Northouse's work on leadership as a guide point to developing (or borrowing tools from that work) in researching members of the surveyed population to examine the treatment effect that the role has had on those organizations. Specifically to see if the various kinds of leadership have had different affects given their place in power and different position from traditional organizational theory. Specifically soon, as this population maybe a unique population to be reviewed in modern research, and the scholarship should provide an ongoing discussion of organizational theory and the impacts of leadership therein. As the other research goes on, those other research relations may change the factors to be studied and stored in scholarship.

Similarly, and the fourth research concept should look at the policy framework and relationships in power by this population of the technology directorship in how their greater powers have affected both the strategic apex and the instructional communities 
they serve. Simply put, by historical artifact, this is a treated population that needs to be researched by more than one frame before the treatment itself is changed and while they still have said power, and how we can learn about such populations function and relate before they are fitted into a more normal organizational structure.

Lastly, the fifth research recommendation is fairly simple: the scope needs to be expanded greatly and repeated in more than one venue. One limiting factor is the survey tool itself; a reconsideration or refinement may be needed to garner better and more substantial results. Specifically, the scope of the level of how this population may be outside of normal organizational theory should be reviewed and measured to see if the power relationships exist in a larger context.

The first of the two policy recommendations are similarly simple: the role of the technology director should be reconsidered in the frame of traditional organizational theory. The jobs themselves need to be clarified if they are truly meant to both touch every member of an organization in power and policy relationships beyond that of the normal strategic apex and command the results unto the same population, or limited to the more traditional roles of advisement or training of the technostructure or support structures. If this is done, this will change the research possibilities of the current populations, as they will return to a more normal mode of organizational theory as described by Mintzberg's theories on organizational structure. This would mean than this treated population would revert to more normalized population and should look and act, and have research results, similar to those traditional structures.

Second, once a hierarchy of needs is established for the profession as a whole, certification and degree establishment should complement the needs hierarchy. Given the 
likely depth of the role of the technology director, the directorship itself will likely touch the mastery of several current master-level degrees. A careful elocution or specialization set of requirements should be established to both provide the instructional support the administrators say they want in a technology director, and the technical skills they require for evaluation. With maturation of the profession, it is likely the view of the job will gain further elements of either the technostructure or support structure of a Mintzberg organization; or it will split into two types of jobs that need accreditation and measurement. 


\section{Appendix A: Informed Consent}

\section{PURPOSE OF THE STUDY}

- The purpose of this case study is to understand the role of and evolution of the role of the District Technology Director.

- This study is in partial fulfillment of requirements for the Educational Leadership \& Policy Analysis EdD program, University of Missouri in Columbia, MO.

\section{PROCEDURE}

- Participants will participate in a survey. If requested, participants will have the opportunity to review the final research paper. Information collected from participants is for the use in a doctoral thesis, and will be published appropriately.

\section{RISKS \& BENEFITS}

- There are no risks or benefits to the participant as a result of participation in this study. Information gathered from the participant will benefit this study, and broaden the understanding of what a Technology Director is in the Southeast Missouri region.

\section{PARTICIPANT CONFIDENTIALITY}

- Your name and district will not be related to any publication or presentation with the information collected about you or your district with the research findings from this study. Instead, the researcher will use a study number rather than your name or district. Your identifiable information will not be shared unless required by law or you give written permission.

\section{PARTICIPANT RIGHTS}

- You have the right to discontinue participation at any time.

COMPENSATION FOR PARTICIPATING IN THE RESEARCH

- None.

EXCLUSIONS

- All participants should have an association administration at a public school district within Southeast Missouri.

PARTICIPANT CERTIFICATION

- I have read this Informed Consent Letter. I understand that if I have any additional questions about my rights as a research participant, I may call Floyd Lockhart III at 573-334-0043 or email him at fhl6df@missouri.edu

- I agree to take part in this study as a research participant. By my signature I confirm that I am at least 18 years old and that I have received a copy of this Informed Consent Letter. 


\section{Appendix B: Survey}

I am a building administrator in a(n):

Elementary School:

Middle School:

Jr. High School:

High School:

Technology Director:

My building has the following technology staff:

Director/Coordinator(s):

Technician(s):

Instructional Designer(s):

Student Employee(s):

Is the role of the Technology Director/Coordinator:

administrative

classified

If it is administrative, what role does the position have (budget, power to fire, etc):

Please rate the following skills important to the position of a technology director/coordinator.

\begin{tabular}{|c|c|c|c|c|c|}
\hline & $\begin{array}{l}\text { Not } \\
\text { important }\end{array}$ & $\begin{array}{l}\text { Somewhat } \\
\text { Important }\end{array}$ & Important & $\begin{array}{l}\text { Very } \\
\text { Important }\end{array}$ & $\begin{array}{l}\text { Not } \\
\text { Applicable }\end{array}$ \\
\hline \multicolumn{6}{|l|}{$\begin{array}{l}\text { Be able to plan a building's network } \\
\text { infrastructure }\end{array}$} \\
\hline \multicolumn{6}{|l|}{$\begin{array}{l}\text { Be able to set up, design, and develop a } \\
\text { classroom learning space. }\end{array}$} \\
\hline \multicolumn{6}{|l|}{$\begin{array}{l}\text { Conduct experiments, analyze data, } \\
\text { interpret and apply results to solve } \\
\text { problems related to optimizing systems and } \\
\text { processes. }\end{array}$} \\
\hline \multicolumn{6}{|l|}{$\begin{array}{l}\text { Prioritize and project maintenance, } \\
\text { sustainability, and growth costs }\end{array}$} \\
\hline \multicolumn{6}{|l|}{$\begin{array}{l}\text { Create and maintain a replacement cycle for } \\
\text { software and hardware resources }\end{array}$} \\
\hline \multicolumn{6}{|l|}{$\begin{array}{l}\text { Configure routers to use routing protocols } \\
\text { in a network topology. }\end{array}$} \\
\hline \multicolumn{6}{|l|}{$\begin{array}{l}\text { Articulate issues concerning ethics for } \\
\text { building computer resources. }\end{array}$} \\
\hline \multicolumn{6}{|l|}{$\begin{array}{l}\text { Articulate issues concerning security } \\
\text { personal safety for district computer } \\
\text { resources. }\end{array}$} \\
\hline \multicolumn{6}{|l|}{$\begin{array}{l}\text { Articulate issues concerning copyright and } \\
\text { acceptable use for district computer } \\
\text { resources. }\end{array}$} \\
\hline \multicolumn{6}{|l|}{$\begin{array}{l}\text { Develop internet or computer based } \\
\text { instructional modules. }\end{array}$} \\
\hline $\begin{array}{l}\text { Create multimedia presentations (audio } \\
\text { podcasts, video podcasts, and similar } \\
\text { presentation) for use in educational settings }\end{array}$ & & & & & \\
\hline
\end{tabular}




\begin{tabular}{|l|l|l|l|l|l|}
\hline $\begin{array}{l}\text { Create an individual professional } \\
\text { development plan to increase teacher } \\
\text { instructional technology skills. }\end{array}$ & & & & & \\
\hline $\begin{array}{l}\text { Analyze current issues and trends in } \\
\text { educational technology. }\end{array}$ & & & & & \\
\hline $\begin{array}{l}\text { Develop a building technology plan for } \\
\text { teaching and learning. }\end{array}$ & & & & & \\
\hline $\begin{array}{l}\text { Consider the philosophical foundations of } \\
\text { curricular practice to determine relevance to } \\
\text { today's technology classroom environment. }\end{array}$ & & & & & \\
\hline $\begin{array}{l}\text { The Technology Director's role is the } \\
\text { function of his or her expertise. }\end{array}$ & & & & & \\
\hline $\begin{array}{l}\text { The Technology Director's role is the } \\
\text { function of his or her position in the district. }\end{array}$ & & & & & \\
\hline
\end{tabular}

Describe the role that the Technology Director plays in the creation and execution of the district's technology plan?

Describe the role that the Technology Director plays in the creation and execution of the district's technology plan? 


\section{Appendix C: Survey Results}

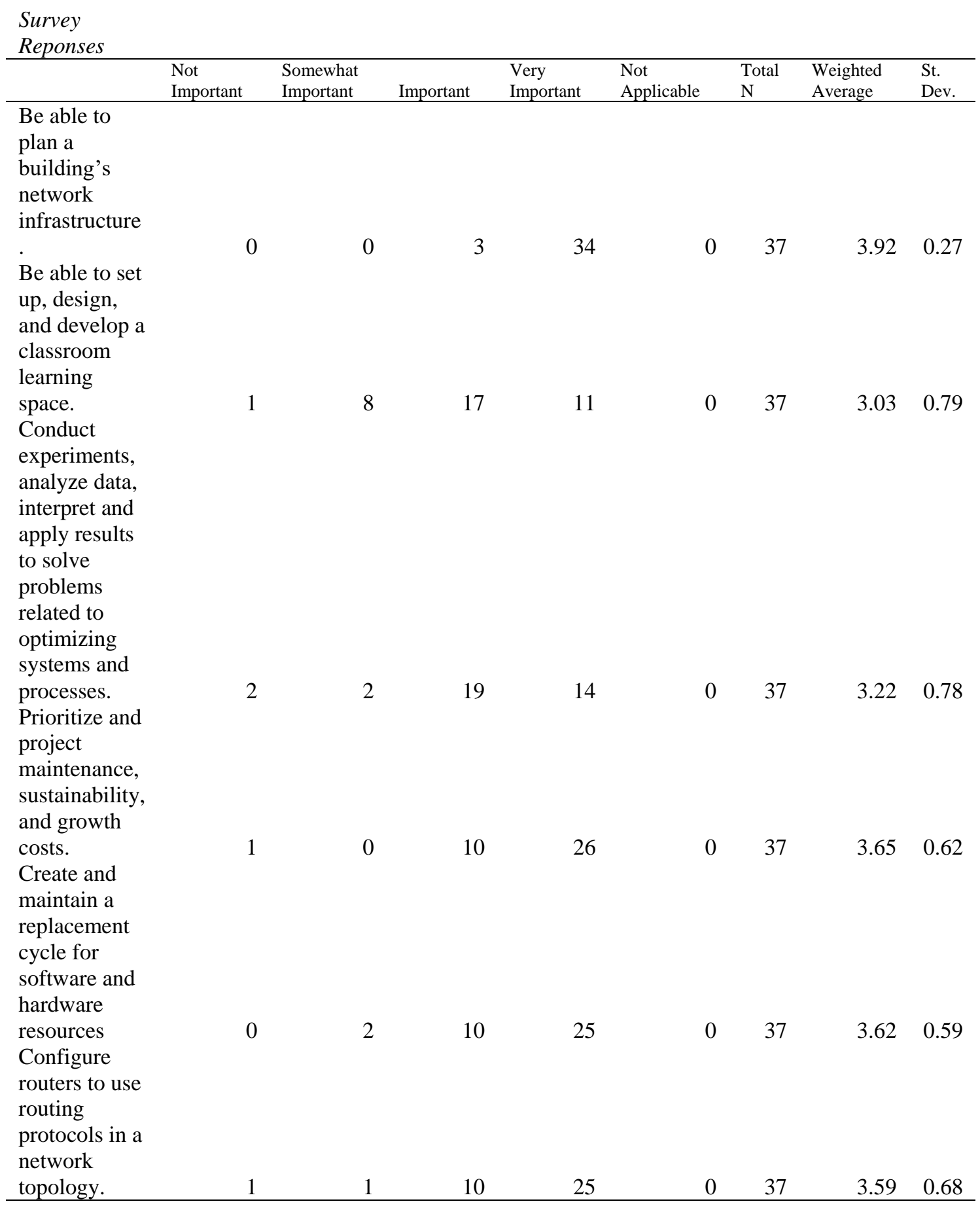




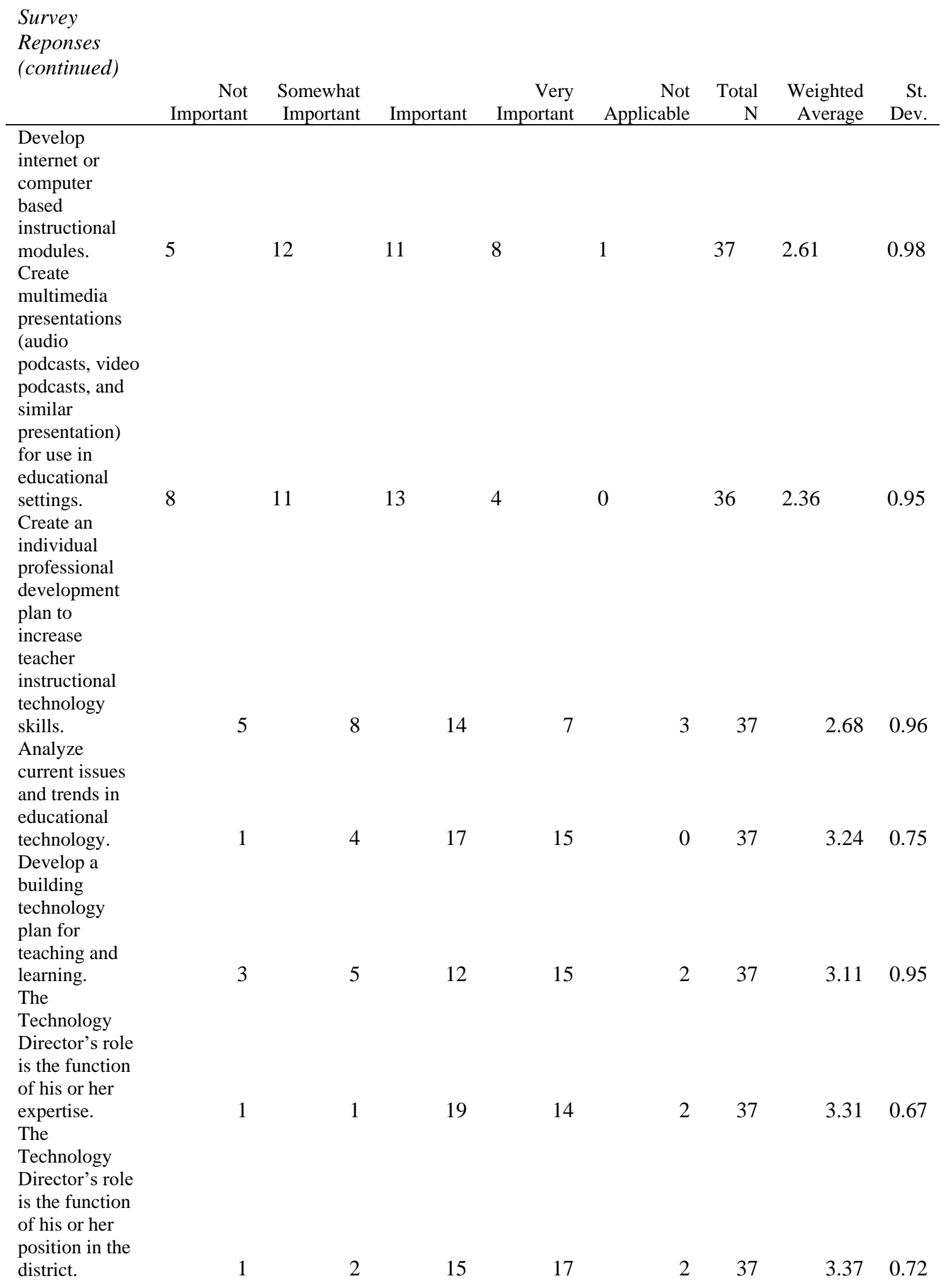




\section{References}

Allen, I., Seaman, J., \& Babson Survey Research, G. (2012). Digital faculty: professors, teaching and technology, 2012. Babson Survey Research Group

Bradshaw, L. (2010, January 1). An analysis of directors' views on educational technology Professional development in 21 st century community learning center programs. ProQuest LLC.

Calas, M. B., \& Smricich, L. (1999). Past postmodernism? Reflections and tentative directions. Academy Of Management Review, 24(4), 649-671. doi:10.5465/AMR.1999.2553246

Crampton, F. E., Thompson, D. C., \& Vesely, R. S. (2004). The forgotten side of school finance equity: The role of infrastructure funding in student success. National Association of Secondary School Principals.NASSP Bulletin, 88(640), 29-56. Retrieved from http://search.proquest.com/docview/216044037?accountid=38003

Creswell, J.W. (2009). Research Design: Qualitative, Quantitative, and Mixed Methods Approaches (3rd ed.) Thousand Oaks, CA: Sage.

Çakiroglu, Ü., Akkan, Y., \& Guven, B. (2012). Analyzing the effect of web-based instruction applications to school culture within technology integration. Educational Sciences: Theory \& Practice, 12(2), 1043-1048.

Dyson, D. D. (2009). Pendulum swings in educational policymaking: The effects of organizational, school, financial and social characteristics on student performance outcomes in michigan school districts. Wayne State University). ProQuest Dissertations and Theses, , 237-n/a. 
French, J. R. P., Raven, B. (2011). The bases of social power. In J. M. Shafritz, J. S. Ott, \& Y. S. Jang (Eds.), Classics of organization theory (7th ed., pp. 291-297). Boston, MA: Wadsworth. (Reprinted from Studies in social power, pp. 150-167, 1959, Ann Arbor, MI: Institute for Social Research, University of Michigan)

Fletcher, G., Schaffhauser, D., Levin, D., \& State Educational Technology Directors Association, (2012). Out of Print: Reimagining the K-12 Textbook in a Digital Age. State Educational Technology Directors Association

Hibner, P. T. (2008). Quantitative study examining the common education and census variables among high achievement public school districts in the state of wisconsin. Edgewood College). ProQuest Dissertations and Theses, , 216-n/a.

ITEEA (2012). AETL standards. Retrieved April 8th, 2013, from http://www.iteea.org/TAA/PDFs/ListingofAETLStandards.pdf

International Society for Technology in Education (2012). Technology director program standards \& rubrics 2012. Retrieved April 13th, 2015, from http://www.iste.org/docs/pdfs/ncate_version_educational_technology_directors_st andards_2011.pdf?sfvrsn=4

Jacobs, H. H., (2010). Curriculum 21: essential education for a changing world. ASCD, Alexandria, VA.

Kalmbacher, S., \& Maxson, D. (2000). Instructional technology academy empowering teachers to lead instructional change. National Association of Secondary School Principals.NASSP Bulletin, 84(616), 42-48.

Mintzberg, H. (2011). The five basic parts of the organization. In J. M. Shafritz, J. S. Ott, \& Y. S. Jang (Eds.), Classics of organization theory (7th ed., pp. 222 - 233). 
Boston, $\quad$ MA: Wadsworth. (Reprinted from General and industrial management: a synthesis of the research, pp. 18-34, 1979, Upper Saddle River, NJ: Prentice-Hall)

Missouri Department of Elementary and Secondary Education. (August 12, 2013) Sixstep process in creating a technology plan. Retrieved August 13, 2013 from http://dese.mo.gov/divimprove/instrtech/techplan/gettingstarted.htm.

Missouri Department of Elementary and Secondary Education (2012). Education technology plan: Ed-tech planning process, key elements, suggested timeline. Retrieved April 15th, 2014, from https://dese.mo.gov/sites/default/files/EdTechPlanningProcessKeyElementsSugge stedTimeline.pdf

Moran, C., \& Selfe, C. L. (1999). Teaching english across the technology/wealth gap. English Journal, 88(6), 48-54.

Loveland, T. (2012). Professional development plans for technology education: accountability-based applications at the secondary and post-secondary level. Technology And Engineering Teacher, 71(7), 26-31.

Stephens, W. E. (2009). The relationship between the expenditure provision of the classroom first for georgia act and five measures of student success. Mercer University). ProQuest Dissertations and Theses, , 159-n/a.

Waterman, B. P. (2009). An exploration of principals' perceptions regarding the value of technology in the success of select high schools in the midwest. Aurora University). ProQuest Dissertations and Theses, , 89-n/a 
Whitehead, B. M., Devon, F. N. J., Boschee, F. (2013). Planning for technology: a guide for school administrators, technology coordinators, and curriculum leaders $\left(^{\text {nd }}\right.$ edition). Corwin Publishing, CA: Sage.

Usselman, S. W. (2010). From Sputnik to SCOT: The historiography of american technology. OAH Magazine Of History, 24(3), 8-14. 


\section{VITA}

Floyd H. Lockhart III was born in Cape Girardeau, Missouri, and grew up running around both Scott County and Cape Girardeau, attending both Scott County Central R-5 and Cape Girardeau Central High School. Afterwards, he stared his Bachelor work at the University of Missouri-Rolla, to finish it at Southeast Missouri State University; where he also earned his Masters of Education in Educational Technology. Lastly, he then attended the University of Missouri-Columbia, where he earned his Ed. D. in 2018 under the advisement of Professor Paul Watkins. Currently, he is the Learning Management Administrator for Southeast Missouri State University. 